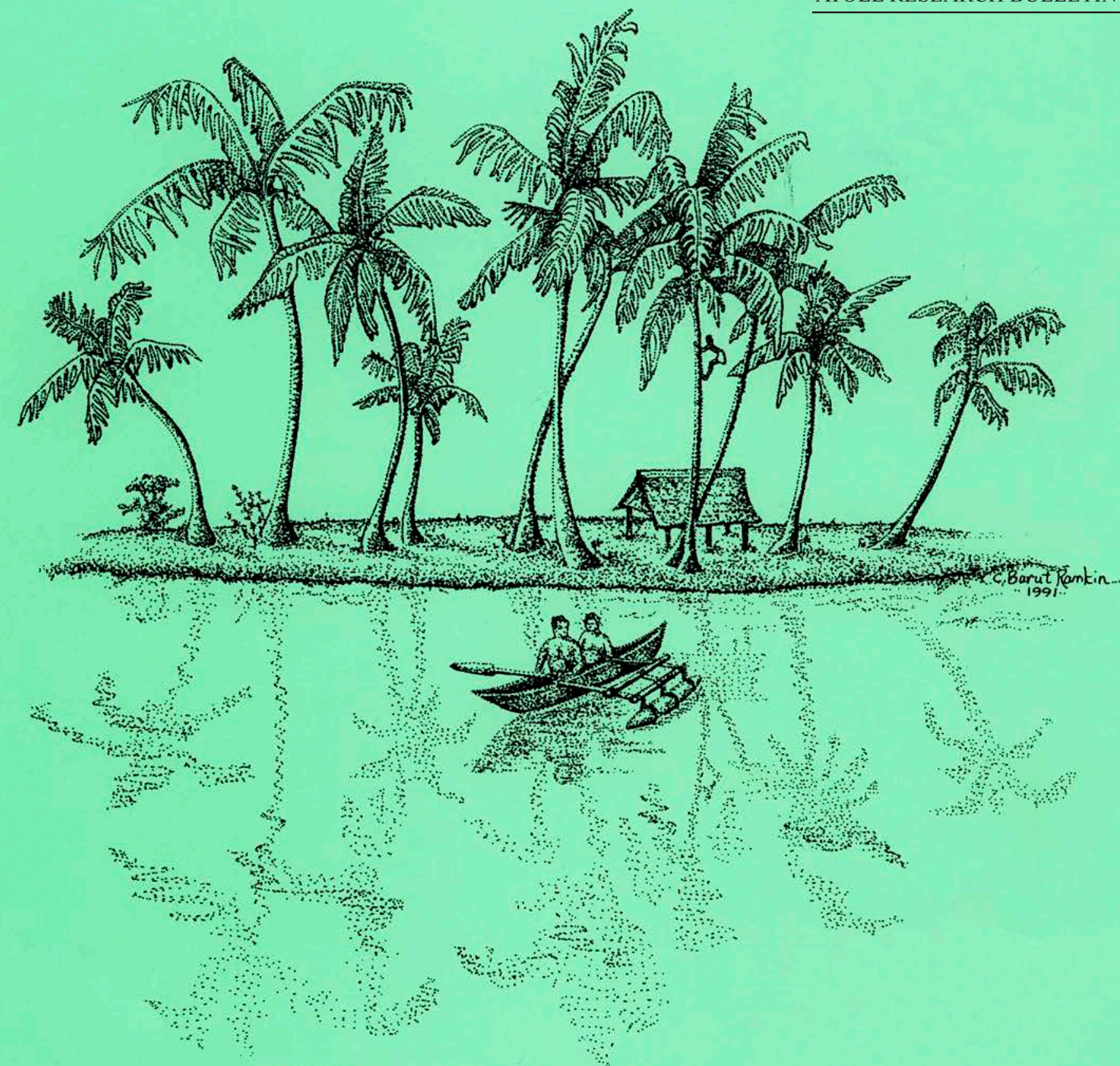

FRINGING REEFS OF REUNION ISLAND

AND EUTROPHICATION EFFECTS

No. 596

PART 1: Long-Term Monitoring of Two Shallow Coral Reef Communities Catherine Tourrand, Odile Naim, Lionel Bigot, Christophe Cadet, Bruce Cauvin,

Stuart Semple, Lucien F. Montaggioni, Pascale Chabanet and Henrich Bruggemann

No. 597

PART 2: Long-Term Monitoring of Primary Producers

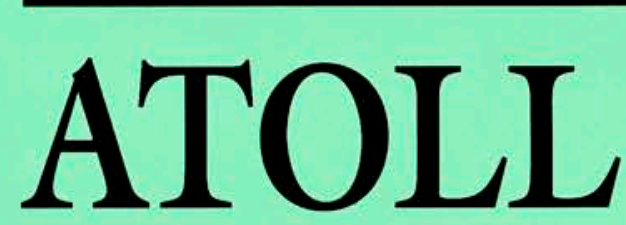

Odile Naim, Catherine Tourrand, Enric Ballesteros, Stuart Semple, Lionel Bigot,

Bruce Cauvin, Pascale Cuet, and Lucien F. Montaggioni

No. 598

PART 3: Long-Term Monitoring of Living Corals

Odile Naim, Catherine Tourrand, Gerard F. Faure, Lionel Bigot, Bruce Cauvin,

Stuart Semple and Lucien F. Montaggioni

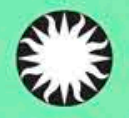

Smithsonian Institution Scholarly Press
RESEARCH

BULLETIN 


\section{FRINGING REEFS OF REUNION ISLAND AND EUTROPHICATION EFFECTS}

PART 1: Long-Term Monitoring of Two Shallow Coral Reef Communities

Catherine Tourrand, Odile Naim, Lionel Bigot, Christophe Cadet, Bruce Cauvin, Stuart Semple, Lucien F. Montaggioni, Pascale Chabanet and Henrich Bruggemann

PART 2: Long-Term Monitoring of Primary Producers

Odile Naim, Catherine Tourrand, Enric Ballesteros, Stuart Semple, Lionel Bigot, Bruce Cauvin, Pascale Cuet, and Lucien F. Montaggioni

PART 3: Long-Term Monitoring of Living Corals

Odile Naim, Catherine Tourrand, Gerard F. Faure, Lionel Bigot, Bruce Cauvin, Stuart Semple and Lucien F. Montaggion

Atoll Research Bulletin No. 598 • 15 November 2013 
All statements made in papers published in the Atoll Research Bulletin are the sole responsibility of the authors and do not necessarily represent the views of the Smithsonian Institution or of the editors of the Bulletin. Articles submitted for publication in the Atoll Research Bulletin should be original papers and must be made available by authors for open access publication. Manuscripts should be consistent with the "Author Formatting Guidelines for Publication in the Atoll Research Bulletin." All submissions to the Bulletin are peer reviewed and, after revision, are evaluated prior to acceptance and publication through the publisher's open access portal, Open SI (http://opensi.si.edu).

Published by SMITHSONIAN INSTITUTION SCHOLARLY PRESS

P.O. Box 37012, MRC 957

Washington, D.C. 20013-7012

www.scholarlypress.si.edu

The rights to all text and images in this publication are owned either by the contributing authors or third parties. Fair use of materials is permitted for personal, educational, or noncommercial purposes. Users must cite author and source of content, must not alter or modify the content, and must comply with all other terms or restrictions that may be applicable. Users are responsible for securing permission from a rights holder for any other use.

ISSN: 0077-5630 (online) 


\title{
FRINGING REEFS OF REUNION ISLAND AND EUTROPHICATION EFFECTS. PART 3: LONG-TERM MONITORING OF LIVING CORALS
}

\author{
BY \\ ODILE NAIM, ${ }^{1,2 *}$ CATHERINE TOURRAND, ${ }^{3,2}$ GERARD F. FAURE, ${ }^{4}$ LIONEL \\ BIGOT, ${ }^{2}$ BRUCE CAUVIN,${ }^{5}$ STUART SEMPLE ${ }^{6}$ and LUCIEN F. \\ MONTAGGIONI $^{7}$
}

\begin{abstract}
Spatio-temporal variations of living coral coverage, species richness and diversity were studied on two fringing reef sites at Saint-Gilles La Saline on Reunion Island from 1987 to 2009. The Site-Toboggan (T) was characterized by oligotrophy, Acropora corals, abundant sea urchins and few primary producers. The SitePlanch'Alizés (P), was characterized by heterotrophy, massive corals, abundant primary producers and rare sea urchins. From the shore to the outer reef slope, both reef flats comprise the back reef at around $1.5 \mathrm{~m}$ deep ('B'), coral zone ' $\mathrm{L}$ ' with large shore-normal strips of coral $0.8 \mathrm{~m}$ deep, coral zone ' $\mathrm{N}$ ' with narrow shore-normal strips of corals at around $0.4 \mathrm{~m}$ deep, and an outer reef flat $(<0.4 \mathrm{~m}$ deep, with breaking surf - not studied).
\end{abstract}

Results are reported in three parts: (1) for 1993, 1996, and 2002, when the survey takes into account the reef flat as a whole on both sites ; (2) for 1987, 1993, 1996 and from 1998 to 2009, when the survey follows changes in two permanent transects on each site ; (3) for 1970 to 2009, in which species richness of Reunion in 2009 is compared to records of species richness over the last 40 years.

In the period 1993 to 2002, a total of 36 coral species was recorded (31 species at T, 19 at P). In 1993, after a 1992-bleaching event, Acropora coverage was low and only 3 species were recorded (A. muricata, A. cytherea, A. abrotanoides). By contrast, in 2002, when Acropora cover was much higher, there were 11 species, but only two at $\mathrm{P}$ in the 1993-2002 interval. The highest coral diversity (Shannon index, $\mathrm{H}^{\prime}$ ) occurred on the $\mathrm{N}$ coral zone at $\mathrm{T}$ in 1996, following an increase from 1993, and after which it declined, as the staghorn coral $A$. muricata strongly increased its cover. By comparison, non-Acropora coverage remained relatively stable at $\mathrm{T}$. At $\mathrm{P}$, coral coverage increased from 1993 to 2002 in both coral zones but only the increase of Porites (Synaraea) rus was statistically significant. Overall, trends in coral cover and diversity indicate both sites were in better health in 2002. Between 1987 and 2009, changes in the smaller fixed LITs were not typical of the overall trends. Among the

\footnotetext{
1 Laboratoire GMGL, Université de Bretagne Sud, Vannes, France

2 Laboratoire ECOMAR, Université de la Réunion, Saint-Denis, France (DOM)

3 Département de Physique, Université de la Réunion, Saint-Denis, France (DOM)

4 Université de Montpellier, France

5 GIP Réserve Nationale Marine de la Réunion, France (DOM)

6 Department of Life Sciences, Roehampton University, England

7 UMR 6536, Université d'Aix-Marseille, France

* Email : odile.naim@univ-reunion.fr
} 
three dominant species, Acropora muricata, Montipora circumvallata and Porites (Synaraea) rus there was no significant temporal variation at either site (reflecting the small sample size and high variance), although the P.rus coverage increased regularly.

The number of coral species on the reef flats may have slightly decreased in the last 40 years. Faure $(1982,2009)$ recorded 74 species in the 1970 s and 71 species in 2009, of which 36 species were recorded on inner reef flats and 62 species on outer reef flats. The number of species recorded by Faure on inner reef flats is the same as we recorded in survey 1. On Saint-Gilles La Saline, the genus Stylophora was totally absent from 2009 surveys (Stylophora pistillata was always rare on Reunion reefs but S. mordax was previously very common on the reef flats and outer slopes). At time of writing, the genus has only been recently observed on wave-exposed reef platforms (reef flats and and outer reef slopes). In 2009, the third species, missing from Faure's records, is Favia rotumana. F. rotumana was very common in 1970s on the outer reef flats, but has not been sighted there.

This study suggests that Acropora abundance and diversity are reliable indicators of autotrophic functioning. Acropora muricata (formerly A. formosa) and A.digitifera are considered as the most eurytopic Acropora species present in Reunion, while Acropora austera is considered as environmentally sensitive and perhaps, one of the sentinel species on the reef flat. Many observations suggest that eurytopic Montipora circumvallata and Porites (Synaraea) rus may both be favored by nutrients and able to tolerate pollutants and large variation of abiotic factors such as temperature and salinity. Acropora, though becoming a rare genus in many areas, has been able to recover rapidly in Reunion, and are resilient in the period covered by the present study.

Key words: Coral reefs, benthic community, living corals, Acropora, Acropora muricata, Acropora austera, Montipora circumvallata, Porites (Synaraea) rus, Stylophora mordax, Favia rotumana, Faviidae, sea urchins, coverage, diversity, species richness, subtidal, stability, bioindicator.

\section{INTRODUCTION}

Health and biodiversity of coral reefs are declining world wide (Gardner et al., 2003; Bellwood et al., 2004; Carpenter et al., 2008; Obura et al., eds, 2008). In the Indian Ocean, human use of coral reefs has increased dramatically in the last few decades (Sheppard, 2000). The coral reefs of the Mascarene Islands (e.g. Reunion, Mauritius and Rodrigues), although far away from major pollution hotspots, are no longer pristine: over-nutrification, hypersedimentation and overfishing are major causes of stress (Naim et al., 2000; Turner \& Klaus, 2005). Coral bleaching has had a medium impact to date, although anomalies in subsurface water temperatures have increased (McClanahan et al., 2007; Tessier et al., 2008; Tourrand et al., 2013).

Stony corals are responsible for the very existence of the reef ecosystems. While alive, coral assemblages form a living veneer and provide shelter for many other reef-dwelling organisms. In the 1970's, the reefs surrouding Reunion were renowned for the high abundance and diversity of corals (Faure, 1982; Bouchon, 1996). Reunion reef flat corals shelter many young fish (Letourneur, 1992; Chabanet, 1994; Letourneur et al., 1998), and associated fauna (Ribes, 1978). Blatant 
degradation was observed from 1983 (Guillaume et al., 1983) but better water management as well as the creation of a marine reserve in 2007 tend to alleviate these impacts. Coral coverage can be an useful indicator of responses to large-scale disturbances (Bruno \& Selig, 2007; Ateweberhan et al., 2011), but the specific composition of the coral assemblages can also be a clear reflection of reef health (Loya et al., 2001). The present paper aims to investigate the evolution of the main coral species present at two selected sites ("Toboggan", Site-T, and "Planch'Alizés", Site-P) from the fringing reef-flat of La Saline-Saint Gilles (western coast of Reunion Island) between the 1970s and 2009.

\section{MATERIAL AND METHODS}

\section{Generalities}

The environmental setting of the Saint-Gilles La Saline reef-flat was described and details of methods are given in part 1 (Tourrand et al., 2013). The reef flat was subdivided into 3 zones or subzones, from beach to front: the back-reef zone (Bzone), the coral zone with Large coral strips (L-coral subzone, at mean depths of $0.80 \mathrm{~m}$ ), and the coral zone with Narrow coral strips (N-coral subzone, at shallower depths of $0.40 \mathrm{~m}$ ). According to the considered site, the different subzones were labelled as follows: the back-reef zone: TB-subzone, and PB-subzone, respectively; the inner coral zone with large coral strips: TL and PL subzones; the outer coral zone with Narrow coral strips: TN and PN subzones; the whole coral zone: $\mathrm{T}_{\mathrm{L}+\mathrm{N}}$ and $\mathrm{P}_{\mathrm{L}+\mathrm{N}}$.

As previously emphasized (Tourrand et al., 2013, Naim et al., 2013), Site-T was characterized by oligotrophic conditions, and a community predominantly composed of Acropora corals, abundant sea urchins, together with primary producers (so-called ACR community), while Site-P was typified by heterotrophic conditions, and a community predominantly composed of massive corals, abundant primary producers, together with rare sea urchins (so-called MAS community). Two quantitative surveys were conducted at both sites, during the hot season when algae are most developed (Naim, 1993; Semple, 1997). Survey 1: percent coverage and species composition of corals were estimated at a 1 centimeter resolution, using the Line Intercept Transect (LIT) method (Lucas \& Seber, 1977; Loya, 1978) at Sites T and $\mathrm{P}$ in 1993, 1996 and 2002. The living coral coverage is noted LCcv. LITs, $50 \mathrm{~m}$ in length, are parallel to the reef front, at fixed intervals of $30 \mathrm{~m}$. At $360 \mathrm{~m}$ out from the back-reef zone, LIT measurements became too hazardous owing to strong waves breaking at depths not exceeding $0.30 \mathrm{~m}$. Accordingly, the outer reef-flat zone was not investigated. In addition, all the coral species observed while swimming in the two test areas were recorded.

Mean coral coverage is given with standard deviation, SD (mean \pm SD). These are calculated as per the following example (shown only for mean calculation here): on Site-T, for a given parameter (e.g. the primary producer coverage), the mean in a subzone (e.g. the back reef, B), for a given-year (e.g. 1993), is denoted TB93, and is the average over the 20 " $10 \mathrm{~m}$-samples" taken on the $50 \mathrm{~m}-\mathrm{LITs}$ located at $30 \mathrm{~m}, 60 \mathrm{~m}$, $90 \mathrm{~m}$ and $120 \mathrm{~m}$. Similarly, the TL93 mean is the average over the 25 " $10 \mathrm{~m}$-samples" taken on the 150 to $270 \mathrm{~m}$ LITs, and the TN93 is the average over the 10 " $10 \mathrm{~m}$ samples" taken on the 300 and 330m LITs. The TB mean is the average over the 60 "10m-samples" taken in the back reef - 20 in each of 1993, 1996 and 2002; the T 
mean is the average over the 165 "10m-samples" taken - 55 in each of 1993, 1996 and 2002.

Survey 2 has focused on the monitoring of two permanent transects, one at each site, respectively at 180m and 270m from the beach, in 1987, 1993, 1996 and from 1998 to 2009 (Table 1).

Table 1. Summary of the 2 surveys. "LIT"= Line Intercept Transect. "T180" means : a permanent transect, marked off every 5 meters at Site-T, distance from the shore line : $180 \mathrm{~m})$.

\begin{tabular}{lcccc}
\hline & Aim of the study & Stations & Method & Period \\
\hline Survey 1 & $\begin{array}{c}\text { Estimation of coverage and } \\
\text { species composition of } \\
\text { major fixed benthic } \\
\text { categories }\end{array}$ & $\begin{array}{c}\text { At each site T and P, LITs } \\
\text { are parallel to the front, } \\
\text { run at fixed intervals of } \\
\text { 30m, from 30m to 330m } \\
\text { off the beach }\end{array}$ & $\begin{array}{c}\text { 50 m-LIT and qualitative } \\
\text { assessment of coral species } \\
\text { located on the 330 } * 50 \mathrm{~m} \\
\text { studied area }\end{array}$ & $\begin{array}{c}1993,1996,2002 \\
\text { hot season }\end{array}$ \\
\hline Survey 2 & $\begin{array}{c}\text { Estimation of coverage and } \\
\text { species composition of } \\
\text { major fixed benthic } \\
\text { categories }\end{array}$ & T 180 and P 270 & Permanent transects & $\begin{array}{c}\text { (2* 20 m) } \\
\text { and each year from 1998 } \\
\text { to 2009, hot season }\end{array}$ \\
\hline
\end{tabular}

To assess patterns in benthic data from all stations in all years, we used nonmetric multidimensional scaling (MDS) and principal component analysis (PCA), and to assess temporal patterns in benthic variation, we used Kruskal-Wallis one-way analysis of variance by ranks: this non-parametric method tests equality of population medians among groups. It is identical to a one-way analysis of variance with the data replaced by their ranks and is an extension of the Mann-Whitney $U$ test to 3 or more groups.

Stony corals were identified using Faure's (1982), Wallace's (1999) and Veron's (2000) nomenclatures, and the Iterative Knowledge Base System (IKBS) developed by Faure et al. (2008a). The IKBS is based on the collection of the Mascarene corals harvested and studied by G. Faure in the 1970's. Note that the dominant species, so-called Acropora muricata according to Wallace (1999) and the Reunion Iterative Knowledge Base System (http://coraux.univ-reunion.fr/), was described as A. formosa in Veron (2000, vol.1, p.176, see discussion) and in previous papers dealing with Reunion reefs.

\section{RESULTS}

Survey 1 (1993-1996-2002, LITs)

Species richness and diversity. From 1993 to 2002, 35 species of living corals, belonging to 12 genera and 8 families, were recorded using LITs at the two sites (Table 2), of which 33 species are Scleractinians and 3 Hydrozoans (Millepora). Two species were not recorded by the LIT method: Pavona cactus, represented by one single colony observed in 1993 in the TL subzone, and Millepora exaesa, although relatively abundant in the PB subzone, but missed by LITs. 
Table 2. Survey 1: Number of families, genera and species observed at both sites (The two species Pavona cactus and Millepora exaesa, not recorded by LITs, are included in the table).

\begin{tabular}{cccc}
\hline Living corals & $\mathrm{T}$ & $\mathrm{P}$ & $\mathrm{T}+\mathrm{P}$ \\
\hline Families & 8 & 6 & 8 \\
Genera & 9 & 9 & 12 \\
Species & 31 & 20 & 36 \\
\hline
\end{tabular}

The species richness is higher at Site-T than at Site-P (Table 2). At both sites, Acropora muricata, Montipora circumvallata and Porites (Synaraea) rus are dominant (Fig. 1). Among Acropora, at Site-T, 11 species form $68.3 \%$ of the living coral coverage (LCcv), of which $76 \%$ were Acropora muricata (Fig. 1, Table 3). At Site-P, Acropora only accounted for $12.6 \% \mathrm{LCcv}$ (of which $99 \%$ were A. muricata). Among non-Acropora species (NAcr), Montipora circumvallata (Mc) and Porites (Synaraea) rus $(P(S) r)$ represented $61 \%$ of NAcr at Site-T and $89 \%$ of NAcr at Site-P, and $M$. circumvallata was roughly twice to three times more abundant than $P$. ( $S$.) rus $(M c / P(S) r$ ratio: T: $2.1 ; \mathrm{P}: 3.0)$.

Table 3. Number of species, relative percentage (in coverage) of Acropora and of the three dominant species at both sites, A.muricata, Montipora circumvallata, Porites (Synaraea) rus (study 1). (*) Pavona cactus at Site-T, Millepora exaesa at Site-P.

\begin{tabular}{c|cc|cc}
\hline & $\mathrm{T}$ & $\mathrm{T}$ & $\mathrm{P}$ & $\mathrm{P}$ \\
\hline & Nb species & $\begin{array}{c}\text { Relative \% } \\
\text { (in coverage) }\end{array}$ & Nb species & $\begin{array}{c}\text { Relative \% } \\
\text { (in coverage) }\end{array}$ \\
\hline Acropora muricata & 1 & 52.2 & 1 & 12.5 \\
Other Acropora species & 10 & 16.1 & 1 & 0.1 \\
\hline Montipora circumvallata & 1 & 13.0 & 1 & 58.4 \\
Porites (Synaraea) rus & 1 & 6.3 & 1 & 19.4 \\
Other non-Acropora species & 17 & 12.4 & 15 & 9.6 \\
\hline Species only observed ${ }^{*}$ ) & 1 & 0.0 & 1 & 0.0 \\
\hline TOTAL & 31 & $100 \%$ & 20 & $100 \%$ \\
\hline
\end{tabular}




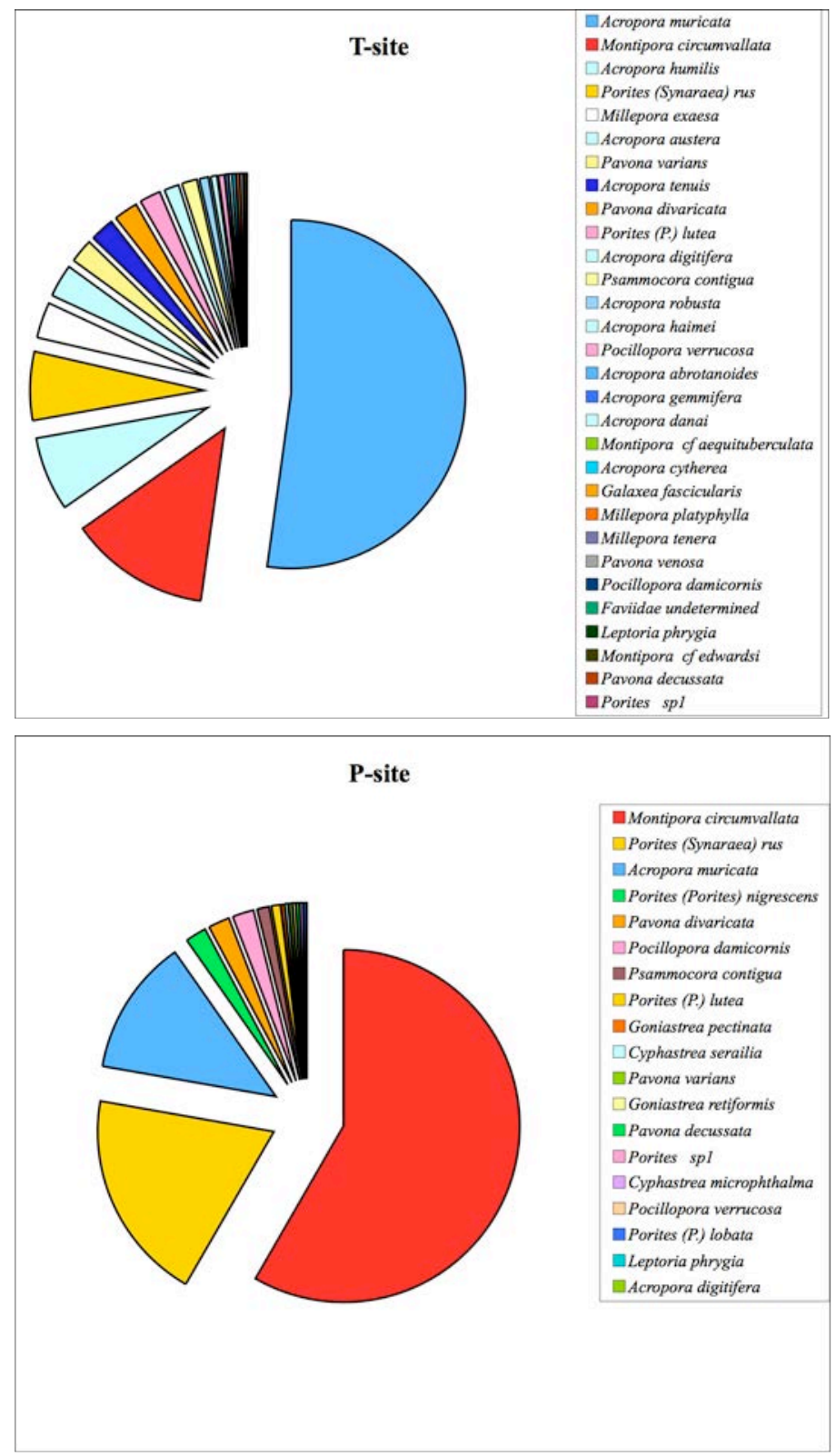

Figure 1: Relative percentage of all the coral species recorded at Site-T and Site-P by LITs (study 1). Porites spl is a branching one. Pavona cactus at Site-T, and Millepora exaesa at Site-P are not represented here (only observed).

Concerning diversity, the shape of the rank species curve indicates that the two sites present a low diversity and are subjected to significant environmental variations (Fig. 2). Considering the first three dominant coral species on the left, Acropora muricata, Montipora circumvallata, Porites (Synaraea) rus, the curve for Site-T lies below the curve for Site-P, expressing the dominance of one single species (Acropora muricata). Then the T-curve goes over the $\mathrm{P}$-one and is far longer, tending to a plateau, thus indicating a higher diversity and a lower ecological disturbance than at Site-P (Frontier, 1985). 


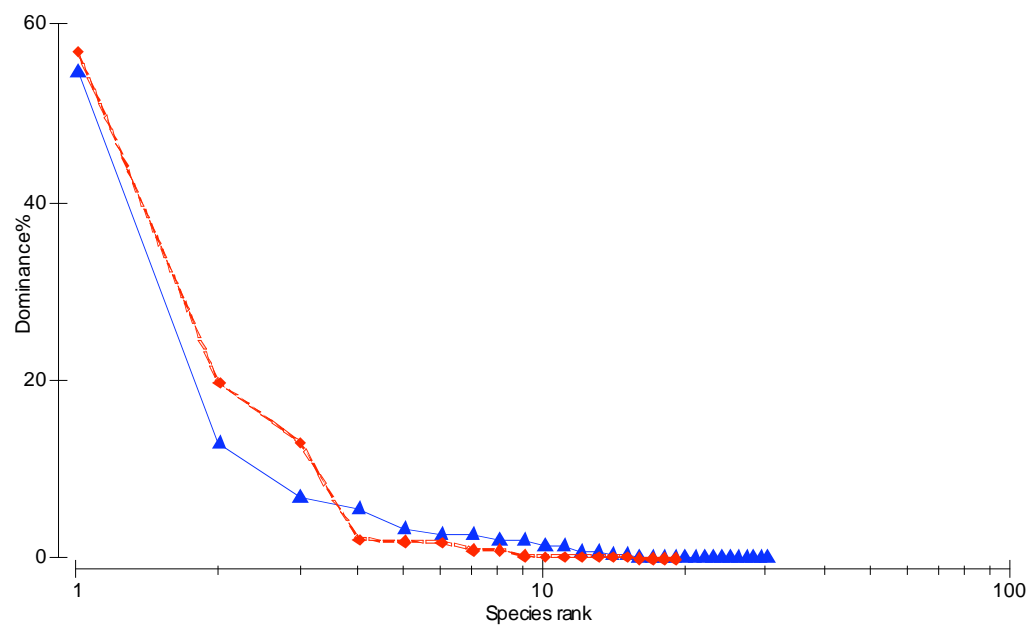

Figure 2: Average ranked abundance curves of living coral species (x-axis: rank, logged), with relative percentage (dominance) on the $\mathrm{y}$-axis at Sites $\mathrm{T}$ and $\mathrm{P}$.

Spatio-temporal variations in abundance and diversity. At both sites, the living coral coverage was similar (T: $17.4 \pm 20.7 \%$; P: $16.2 \pm 16.9 \%)$, but was higher in the PB than in the TB subzone, and higher in the TN than in the PN subzone. According to the standard deviation, living corals appear to occur randomly at Site-P and mostly in aggregated patches at Site-T.

At Site-T, H' increased from 1993 to 1996 and decreased from 1996 to 2002 while at Site-P, it was increasing from 1993 to 2002 (Fig. 3a). Similar variations occurred on the different subzones (Fig. 3b), except in TB where H' did not vary very much and in PN where diversity dropped in 2002. In the L-coral subzone, H' was approximately the same at both sites in 1993 and 1996, but became markedly higher in the PL subzone than in the TL one in 2002. From 1993 to 2002, the highest diversity (Shannon index, H') occurred in the TN subzone, and in 1996 (Fig. 3a,b).
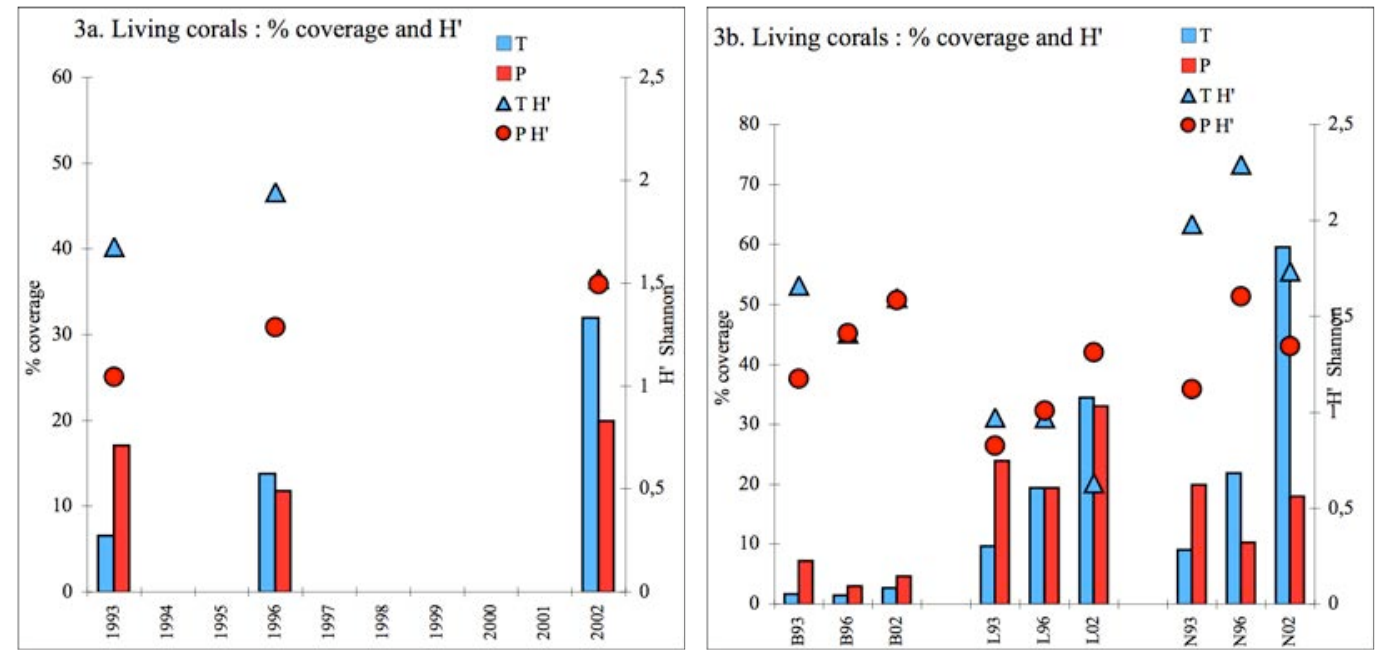

Figure 3a \& 3b: Spatio-temporal variation from 1993 to 2002 of the coverage of living corals (in \%) and biodiversity ( $\mathrm{H}^{\prime}$ Shannon index). Left : across the total site, right: in the three geomorphological zones, $\mathrm{B}=$ back reef, $\mathrm{L}=$ inner zone of Large coral strips, $\mathrm{N}=$ outer zone of Narrow coral strips. 

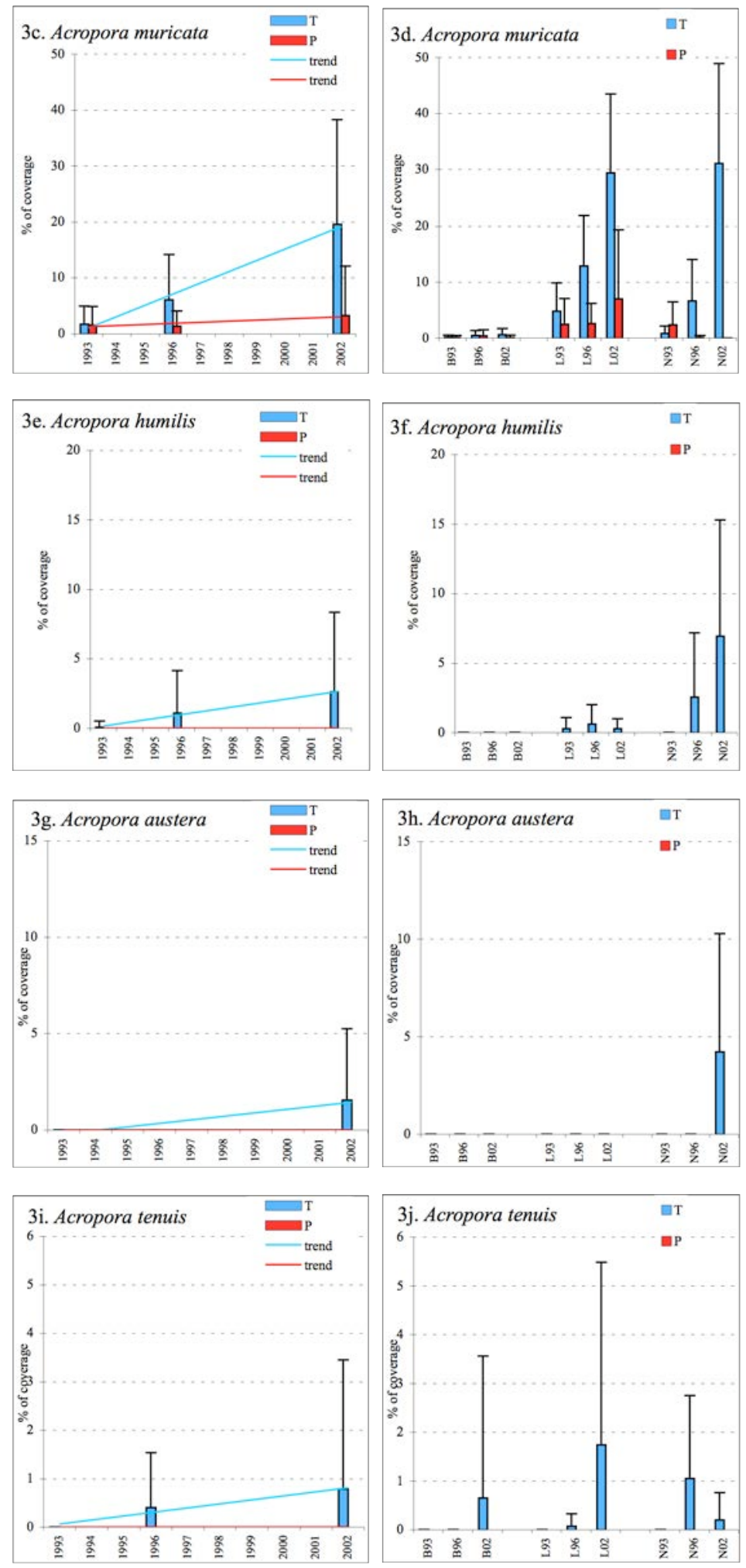

Figure $3 \mathrm{c}$ to $3 \mathrm{j}$ : Spatio-temporal variation from 1993 to 2002 of the coverage of the dominant Acropora species (in \%). Left : across the total site, right: in the three geomorphological zones. 

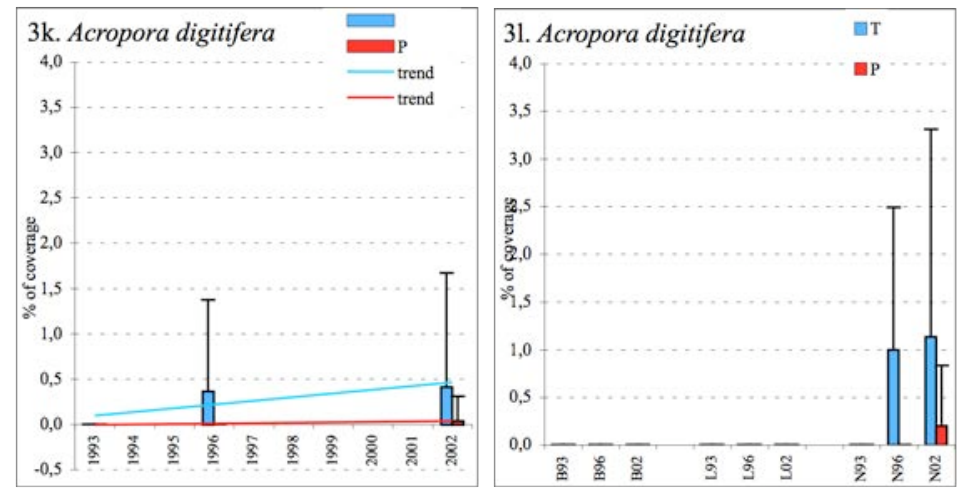

Figure 3k \& 31 : Spatio-temporal variation from 1993 to 2002 of the coverage of the dominant Acropora species (in \%). Left : across the total site, right: in the three geomorphological zones.

From 1993 to 2002, considering Acropora at Site-T, the cover rate of the five dominant species, A. muricata, A. humilis, A. austera, A. tenuis, A. digitifera, was increasing, but only A. muricata and A.humilis coverages increased significantly (Fig. 3c to Fig. 31, Table 4). In 1993 (year when the lowest Acropora coverage occurred in the survey time), only 3 species were recorded (A.muricata, A. cytherea, A. abrotanoides), while in 2002 (highest coverage), 11 Acropora were found (see list of species in Fig. 1). Coverage of massive species remained stable.

At Site-P, numerous species, including Acropora formosa, moderately increased in abundance from 1993 to 2002, especially in the PL and/or PN subzones, while a significant increase in Porites (Synaraea) rus was restricted to the PN subzone (Fig. 3, Table 4). Pocillopora damicornis was the only species that decreased in the PN subzone, but once more moderately. These trends, although not significant, indicated better health conditions at Sites T and P in 2002. 

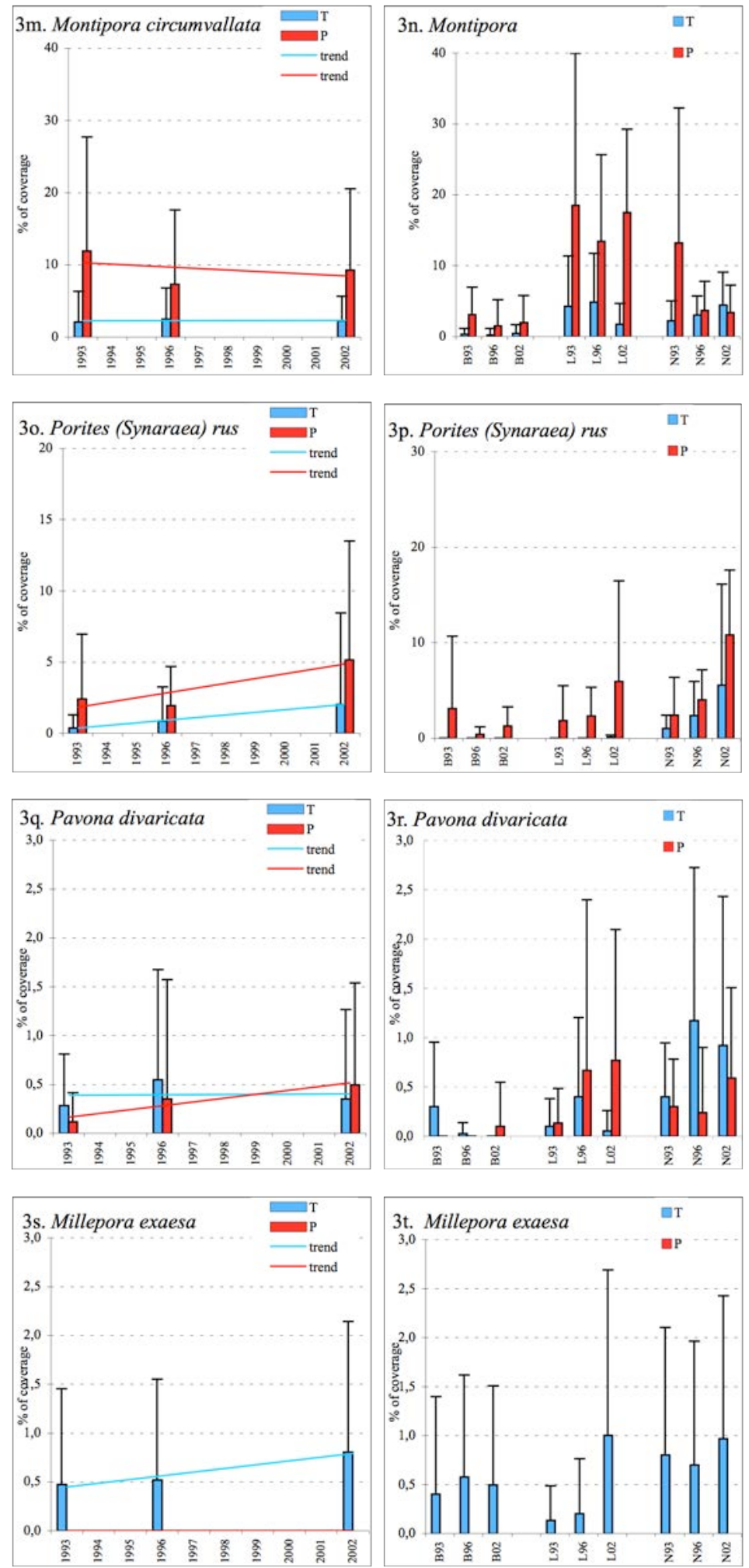

Figure 3m to 3t : Spatio-temporal variation from 1993 to 2002 of the coverage of the dominant Acropora species (in \%). Left : across the total site, right: in the three geomorphological zones. 

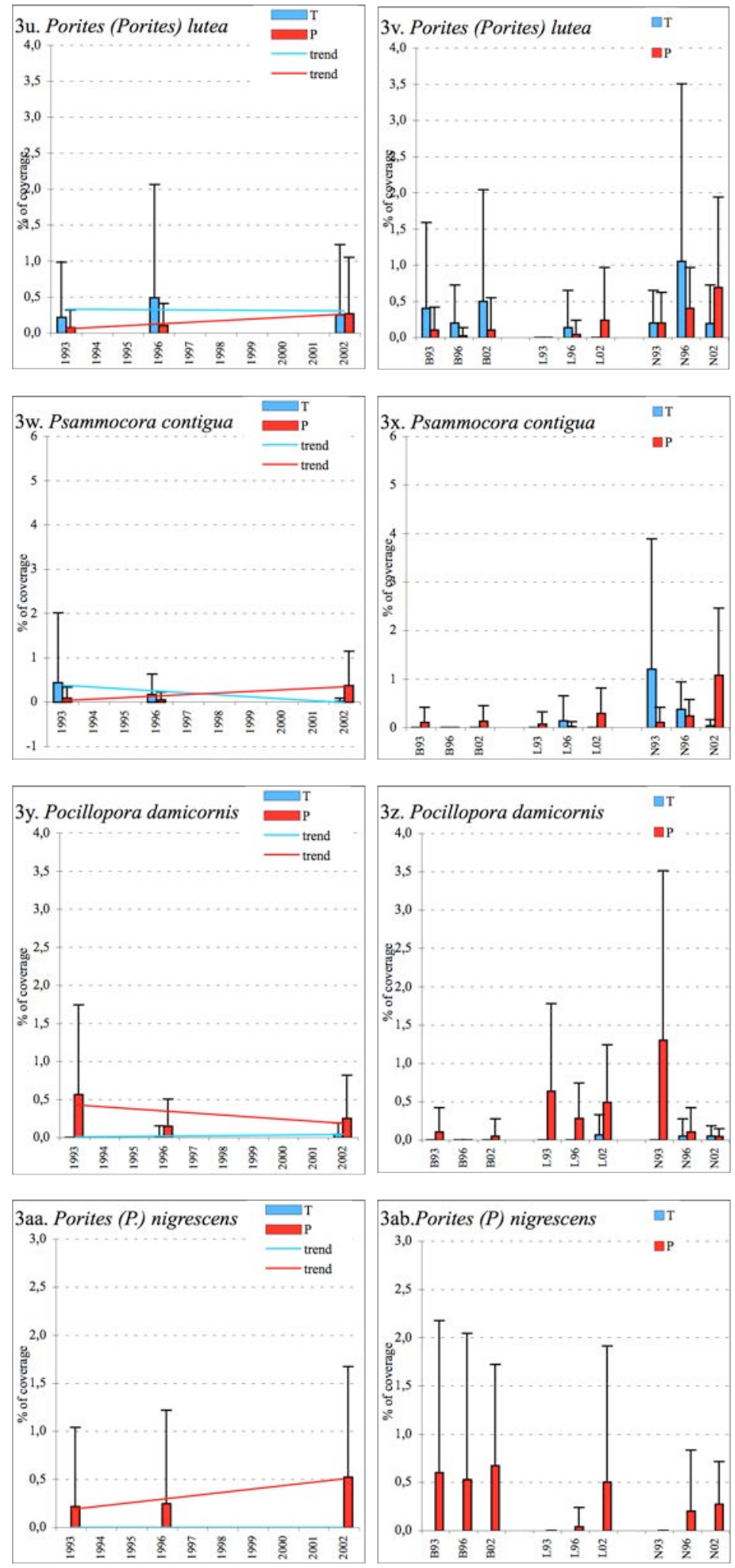

Figure 3u to 3ab : Spatio-temporal variation from 1993 to 2002 of the coverage of the dominant Acropora species (in \%). Left : across the total site, right: in the three geomorphological zones. 
Table 4. Survey 1 (whole site, 1993, 1996, 2002): Kruskal-Wallis test between means $(\mu)$ of the variables in the 3 different years, at the two sites ( $\mathrm{T}=$ Toboggan, $\mathrm{P}=$ Planch'Alizés) (>: significant increase, <: significant decrease, Ns: non significant).

\begin{tabular}{|c|c|c|c|c|c|c|c|c|}
\hline & & $\begin{array}{c}\mu 1993- \\
\mu 1996\end{array}$ & $\begin{array}{l}\mu 1993- \\
\mu 2002\end{array}$ & $\begin{array}{l}\mu 1996- \\
\mu 2002\end{array}$ & & $\begin{array}{l}\mu 1993- \\
\mu 1996\end{array}$ & $\begin{array}{l}\mu 1993- \\
\mu 2002\end{array}$ & $\begin{array}{l}\mu 1996 \\
\mu 2002\end{array}$ \\
\hline \multirow[t]{4}{*}{ Acropora muricata } & $\mathrm{T}$ & $\begin{array}{c}> \\
\mathrm{p}=0.0247\end{array}$ & $\begin{array}{c}\gg>>> \\
\mathrm{p}=0.0000\end{array}$ & $\begin{array}{c}> \\
\mathrm{p}=0.0134\end{array}$ & $\mathrm{P}$ & Ns & Ns & Ns \\
\hline & TB & $\mathrm{Ns}$ & $\mathrm{Ns}$ & $\mathrm{Ns}$ & PB & Ns & Ns & Ns \\
\hline & $\mathrm{TL}$ & $\begin{array}{c}>> \\
\mathrm{p}=0.0093\end{array}$ & Ns & Ns & PL & Ns & Ns & Ns \\
\hline & $\mathrm{TN}$ & Ns & $\begin{array}{c}\gg>> \\
\mathrm{p}=0.0000\end{array}$ & $\begin{array}{c}\gg> \\
\mathrm{p}=0.0001\end{array}$ & PN & Ns & Ns & Ns \\
\hline \multirow[t]{4}{*}{ Acropora humilis } & $\mathrm{T}$ & Ns & $\begin{array}{c}> \\
\mathrm{p}=0.0174\end{array}$ & Ns & $P$ & absent & absent & absent \\
\hline & TB & Ns & $\mathrm{Ns}$ & Ns & PB & absent & absent & absent \\
\hline & $\mathrm{TL}$ & Ns & Ns & Ns & PL & absent & absent & absent \\
\hline & $\mathrm{TN}$ & Ns & Ns & $\begin{array}{c}> \\
\mathrm{p}=0.0188\end{array}$ & PN & absent & absent & absent \\
\hline \multirow[t]{4}{*}{$\begin{array}{c}\text { Porites (Synaraea) } \\
\text { rus }\end{array}$} & $\mathrm{T}$ & Ns & Ns & Ns & $\mathrm{P}$ & Ns & $\begin{array}{c}> \\
\mathrm{p}=0.0220\end{array}$ & Ns \\
\hline & TB & Ns & Ns & Ns & PB & Ns & Ns & Ns \\
\hline & $\mathrm{TL}$ & Ns & Ns & Ns & PL & Ns & Ns & Ns \\
\hline & $\mathrm{TN}$ & Ns & Ns & Ns & PN & Ns & $\begin{array}{c}>> \\
\mathrm{p}=0.0093\end{array}$ & Ns \\
\hline
\end{tabular}

The eight dominant species on both sites. Among the eight dominant species during the survey, three are Acropora and five are massive corals. Multidimentional scaling (MDS) shows the exact location on the reef flat of the three dominant Acropora. Acropora muricata and A. humilis were mostly located in the TL and TN subzones, and $A$. austera only in the TN subzone (Fig. $\mathbf{4 b}, \mathbf{4 c}, \mathbf{4 d}$ ).

Among massive corals, MDS results indicate that the two dominant species, Montipora circumvallata and Porites (Synaraea) rus, mostly occur in the PB and PL subzones, while Pavona divaricata grew in both inner sites (back reefs and L-zones). Porites (Porites) lutea were ubiquitous at both sites, but the coverage of P.lutea is higher at Site-T than at Site-P because of the occurrence of larger colonies (Fig. 4e, $\mathbf{4 f}, \mathbf{4 g}, \mathbf{4 h}, \mathbf{4 i}$ ). Millepora exaesa is abundant on both back reefs but was not recorded by LITs in the PB subzone. 
4a. Two dimensional-MDS configuration, all benthic data (see details in Tourrand et al., 2013) Site-T (triangles) and Site-P (circles). Back reef= green, L-zone= orange, $\mathrm{N}$-zone: blue

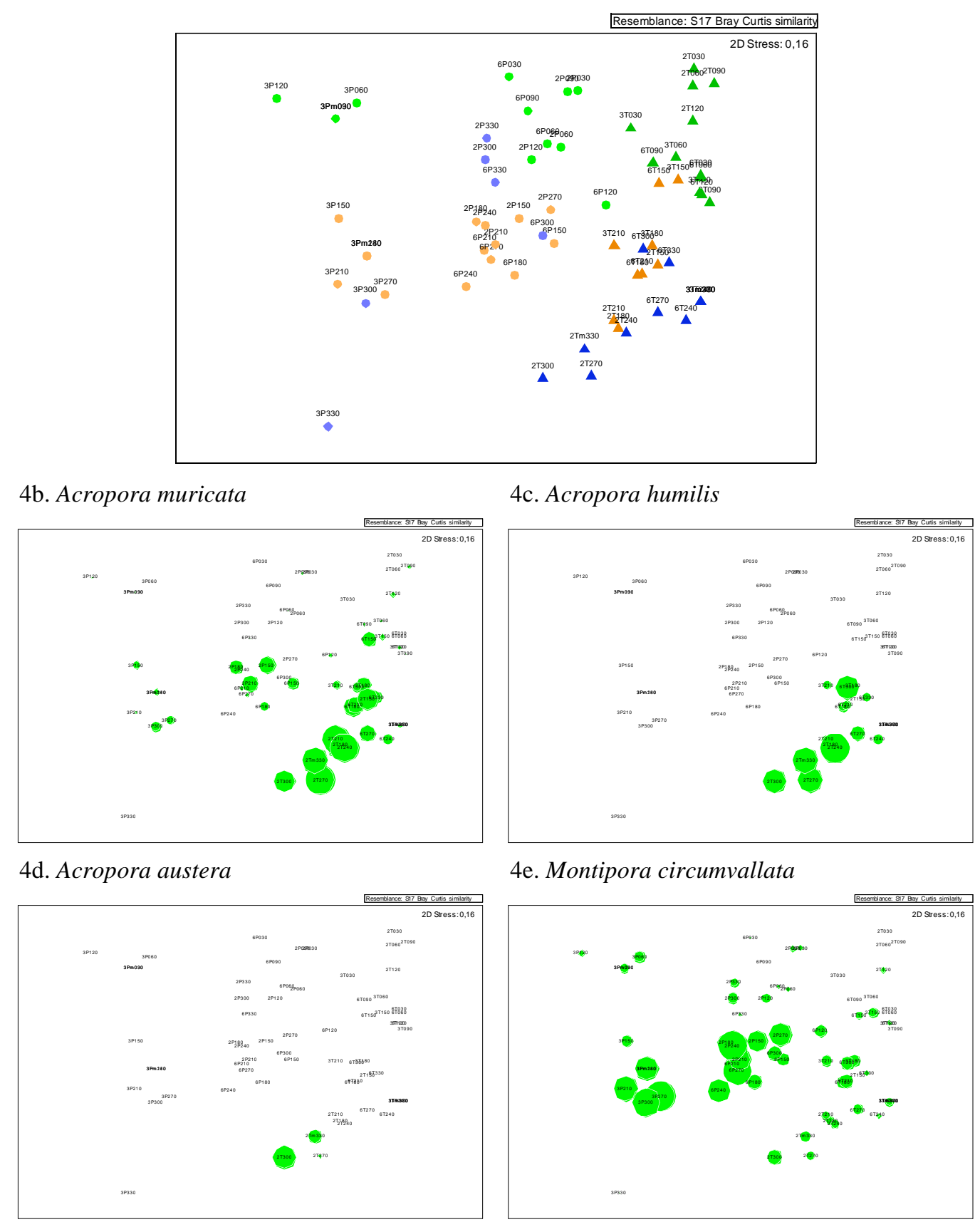

Figures 4a to 4e: Two dimensional-MDS configuration with surimposed bubbles obtained with a hierarchical clustering of the $58 * 50 \mathrm{~m}$-LIT (all benthic data: corals, algae, etc., echinoderms and territorial fish included). 
4f. Porites (Synaraea) rus

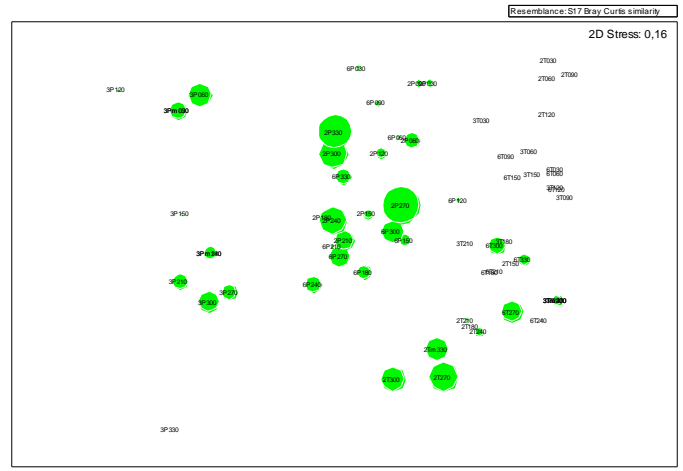

4f. Porites (Synaraea) rus

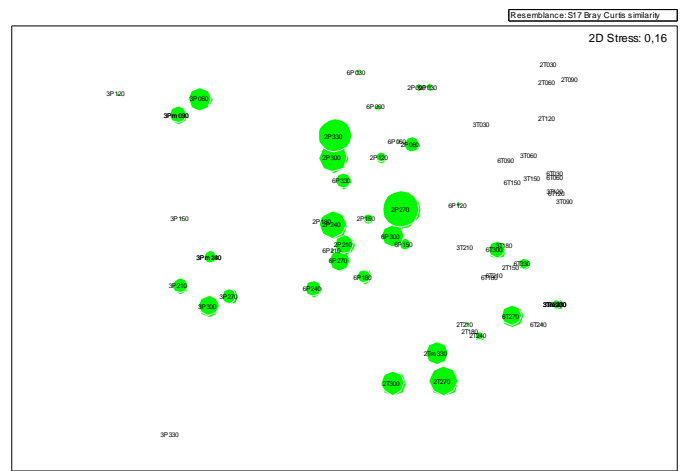

4h. Millepora exaesa

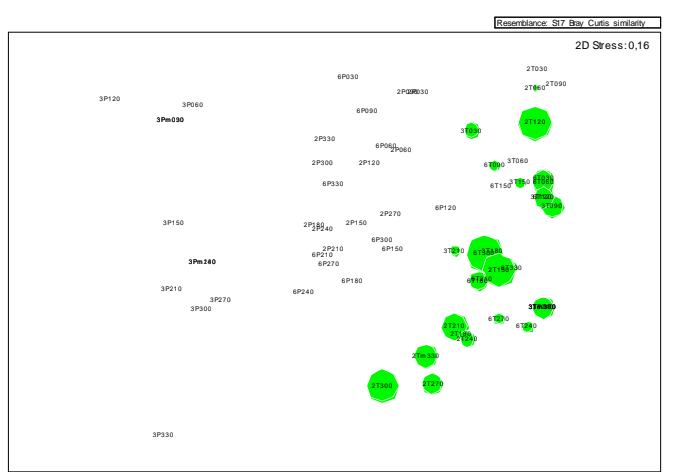

4g. Pavona divaricata

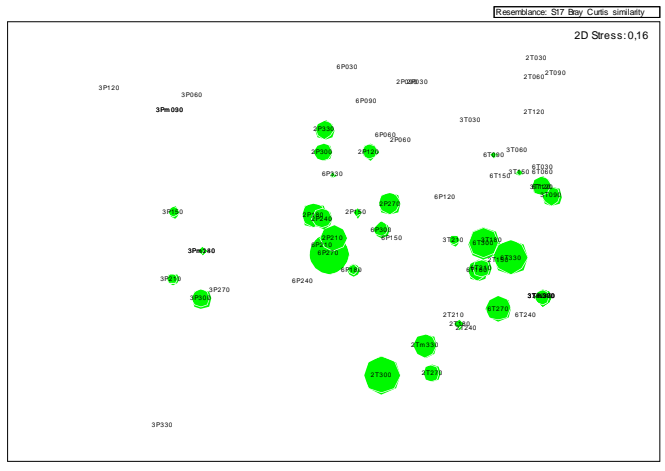

4g. Pavona divaricata

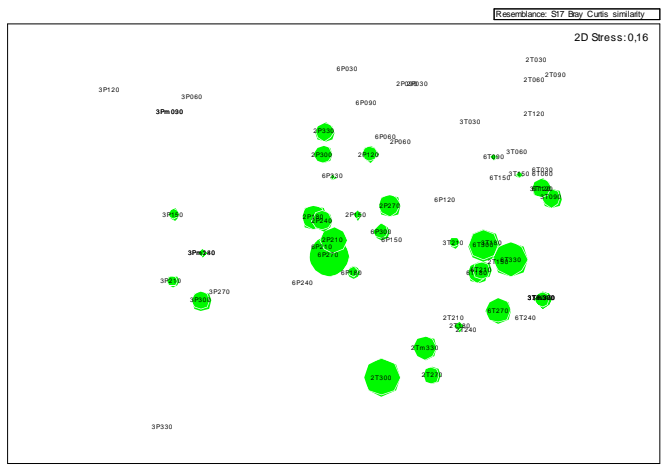

4i. Porites (Porites) lutea

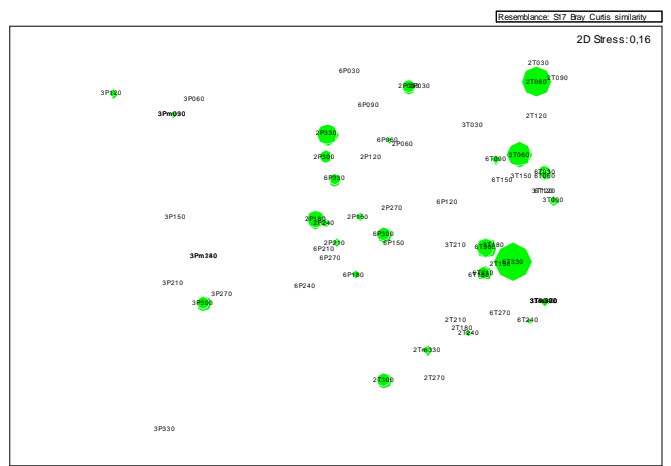

Figure 4f to 4i: Two dimensional-MDS configuration with surimposed bubbles obtained with a hierarchical clustering (all benthic data: corals, algae, etc., echinoderms and territorial fish included).

Principal Component Analysis (PCA) (survey 1, 1993-1996-2002 data together). Using PCA, Factor1 that explains $39.5 \%$ of the variance, opposes the back reefs and coral zones (including both Large and Narrow coral strip subzones), owing to the opposition between the dominance of Porites (Porites) nigrescens in the PB subzone and that of Acropora muricata and A. humilis in the T-coral zone (Fig. 5).

Factor 2 (24\% of the variance) clearly separates the Sites T from P. Discrimating species are given in table 6 (discussion section). 


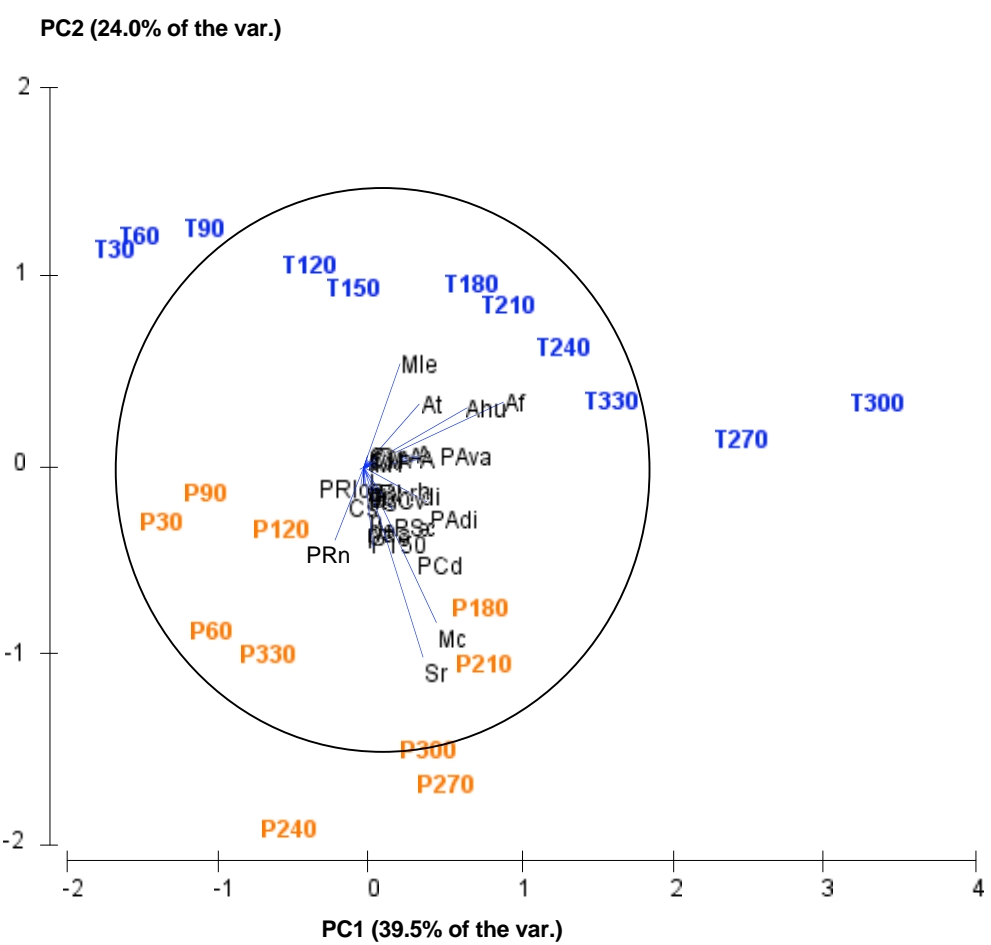

Figure 5: PCA on living corals data, all years $(1993,1996,2002)$ together. $\mathrm{T}=$ Site-Toboggan, $\mathrm{P}=\mathrm{Site}-$ Planch'Alizés, T30= Site-Toboggan, 30 meters from the beach. Af= Acropora muricata, Ah= Acropora humilis, At = Acropora tenuis, MIex= Millepora exaesa, Mc= Montipora circumvallata, $\mathrm{PAdi}=$ Pavona divaricata, $\mathrm{PAva}=$ Pavona varians, $\mathrm{PRlo}=$ Porites $($ Porites $)$ lobata, $\mathrm{PRn}=$ Porites (Porites) nigrescens, $\mathrm{Sr}=$ Porites (Synaraea) rus.

Coverage and richness according to the distance to shore (survey 1, 1993, 1996, 2002 together). The variation in the living coral coverage, from the beach seawards, is relatively similar at both sites (Fig. 6a).

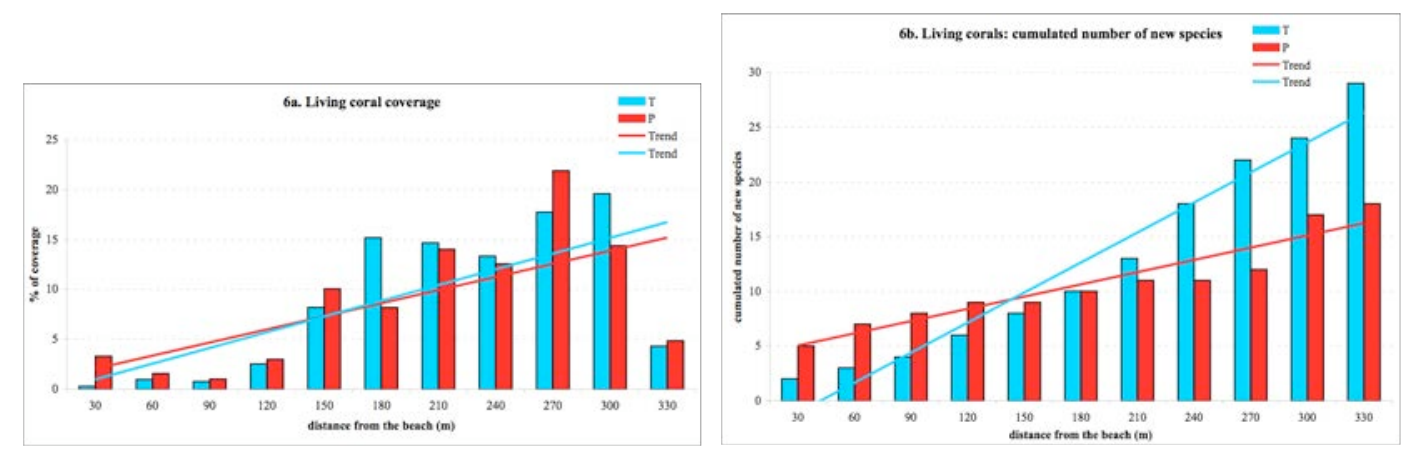

Figure 6a \& 6b: living coral coverage and cumulative number of new species of living corals as a function of the distance from the beach.

However, at Site-T, the occurrence of new species increased rapidly from the station at $210 \mathrm{~m}$ to the reef front (Fig. 6b). A.muricata, A. tenuis, A. cytherea and A. humilis were the only Acropora species occurring from 30-210 m interval, whereas two-third of Acropora species occurred within the 240-330 m interval. Faviidae ( 1 species) only occurred at the $330 \mathrm{~m}$-station. 
By contrast, at Site-P, the number of coral species was high near the shore and increased weakly towards the reef front. Faviidae (5 species) occurred within the 210$330 \mathrm{~m}$ interval.

Survey 2: from 1987 to 2009

This study, based on the permanent transects T180m and P270m, uses in part the data gained from the Global Coral Reef Monitoring Network (GCRMN). As stated in Tourrand et al., 2013 (Survey 3, section "results"), the monitoring period was divided into 3 periods: 1987-1998, 1999-2003 and 2004-2009. However, the high variance in the results did not allow any detection of significant variations in coral coverage, although Porites (Synaraea) rus coverage steadily increased at P270 from 1987 to 2009 (Fig. 7, Table 5).

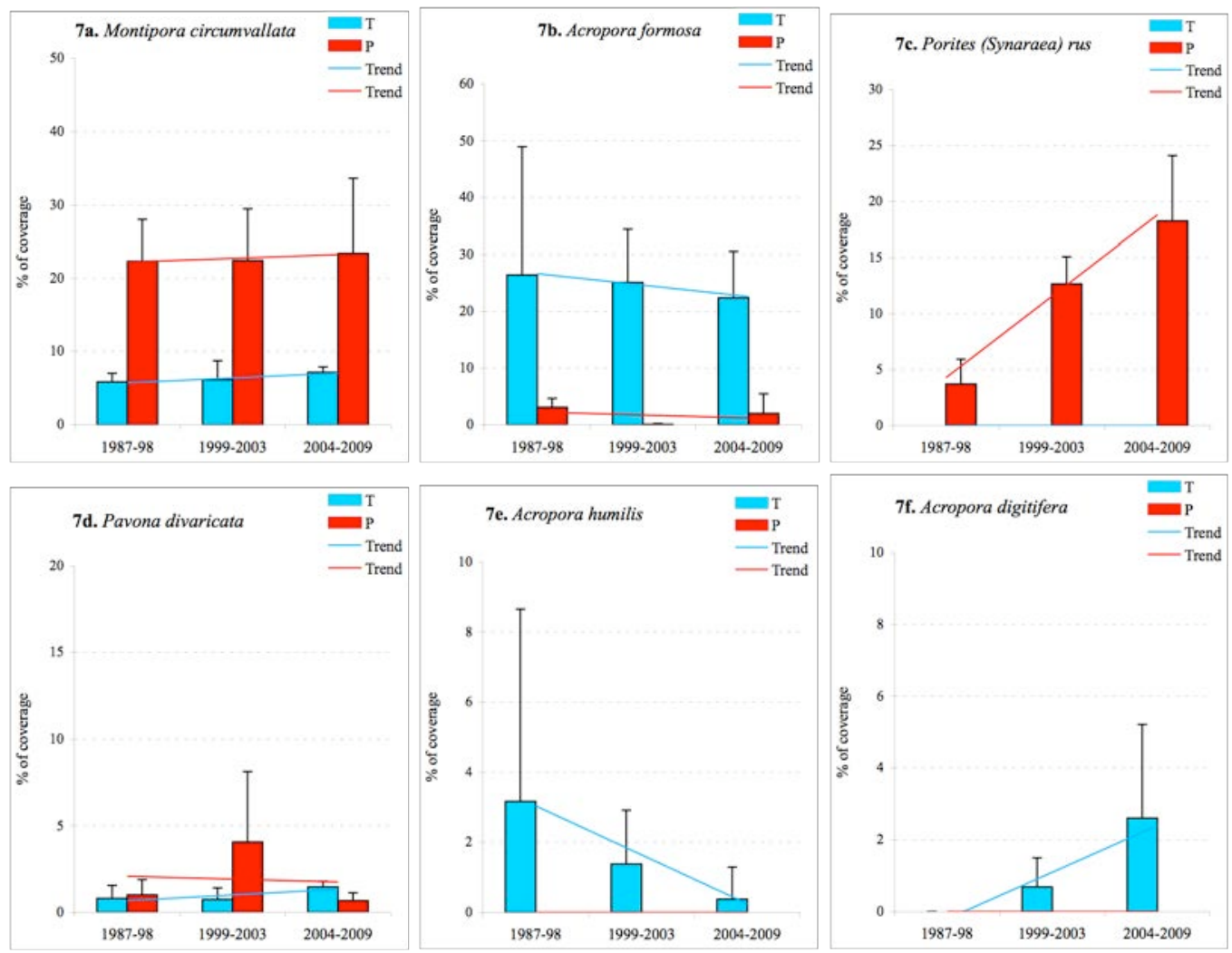

Figure 7a to 7f. Survey 2: temporal variations of the dominant species on the T180 and the P270 transects.

Table 5. Study 2 (GCRMN data): Kruskal-Wallis test between means $(\mu)$ of the variables in the 3 "year-blocks", on the two permanent transects (T180= "Toboggan" $180 \mathrm{~m}$ off shore, $\mathrm{P}=$ "Planch'Alizés", $270 \mathrm{~m}$ off shore). (Ns: non significant).

\begin{tabular}{|c|c|c|c|c|c|c|c|c|}
\hline & & $\begin{array}{c}\mu(1987- \\
1998) \\
-\mu(1999- \\
2003)\end{array}$ & $\begin{array}{c}\mu(1999- \\
2003) \\
-\mu(2004- \\
2009)\end{array}$ & $\begin{array}{c}\mu(1987- \\
1998) \\
-\mu(2004- \\
09)\end{array}$ & & $\begin{array}{c}\mu(1987- \\
1998) \\
-\mu(1999- \\
2003)\end{array}$ & $\begin{array}{c}\mu(1999- \\
2003) \\
-\mu(2004- \\
2009)\end{array}$ & $\begin{array}{c}\mu(1987- \\
1998) \\
-\mu(2004- \\
2009)\end{array}$ \\
\hline Acropora muricata & T180 & $\mathrm{Ns}$ & Ns & Ns & P270 & $\mathrm{Ns}$ & Ns & Ns \\
\hline $\begin{array}{c}\text { Montipora } \\
\text { circumvallata }\end{array}$ & & Ns & Ns & Ns & & Ns & Ns & Ns \\
\hline $\begin{array}{c}\text { Porites (Synaraea) } \\
\text { rus }\end{array}$ & & Ns & Ns & Ns & & Ns & Ns & Ns \\
\hline
\end{tabular}


The apparent inverse variation in the coverage of A.humilis and A.digitifera (Fig. 7e, 7f) may be due to the fact that the two species can be confused.

\section{DISCUSSION}

Coral communities at Sites T and P: metabolism and characteristic species

MAS: a phase shift of ACR ? From 1993 to 2002, athough the living coral coverage was not significantly different between Sites $\mathrm{T}$ and $\mathrm{P}$, the composition of the coral community was totally dissimilar. Site-T was dominated by Acropora while Site-P was dominated by non-Acropora corals. Table 6 gives the most characteristic species on the two reef flats (results from PCA, whole site, F2 axis). For Acroporidae, Acropora was a distinguishing genus, but Montipora was not (see discussion below). The distributional pattern of Pavona and Porites did not allow the two sites to be differentiated. Faviidae are mostly recorded at Site-P. By contrast, Galaxea has never been observed at Site-P.

Table 6. Discriminating coral species in PC2 (24.0\% of the variance) in order of importance (Survey 1, PCA on living coral coverage, 1993-1996-2002-data combined).

\begin{tabular}{cc}
\hline Site-T & Site-P \\
\hline 1. Acropora muricata & 1. Montipora circumvallata \\
2. Acropora humilis & 2. Porites (Synaraea) rus \\
3. Acropora austera & 3. Pocillopora damicornis \\
4. Acropora cytherea & 4. Porites (Porites) nigrescens \\
5. Galaxea fascicularis & 5. Psammocora contigua \\
6. Pavona varians & 6. Pavona divaricata \\
7. Acropora robusta & 7. Cyphastrea serailia \\
8. Porites (Porites) lutea & 8. Goniastrea pectinata \\
9. Acropora danai & 9. Cyphastrea microphthalma \\
10. Acropora haimei & 10. Goniastrea retiformis \\
11. Montipora cf aequituberculata & 11. Pavona decussata \\
12. Pavona venosa & \\
13. Acropora digitifera & \\
14. Millepora platyphylla & \\
15. Acropora gemmifera & \\
16. Montipora cf edwardsi & \\
17. Acropora abrotanoides &
\end{tabular}

Despite these differences, the four dominant coral species were the same at both sites: Acropora muricata, Montipora circumvallata, Porites (Synaraea) rus and Pavona divaricata. Otherwise, from coast to reef front, the number of newly appearing coral species was slower and remained lower at Site-P (Fig.6). This indicates that, at Site-P, ambient conditions were conducive to the growth of some species, but did not permit the hard coral community to reach a high diversity, even in the outer subzone PN, and this despite the fact the reef is very exposed to swells. At Site-T, A.muricata, A. tenuis, A. cytherea and A. humilis were the only Acropora present in the back-reef zone, whereas two-third of Acropora species occurred on the coral zone, within the $240-330 \mathrm{~m}$ interval.

Classified as ruderal or r-strategist by Edinger and Risk (2000), Acropora genus and, especially A.muricata/formosa, have dominated and still are dominating the reef flat overstory space in Reunion (Faure, 1982; Despinoy et al., 2000; Naim, 2002, 2006; Bruggemann et al., 2007; Faure, 2009). When A. formosa/muricata is dominant, as at Site-T in 1987 or 2002, very few substrates are suitable for the 
settlement of coral larvae. This limits the recruitment by sexual reproduction of any species. A. formosa/muricata recruitment is, however, not affected as it reproduces very often by fragmentation of already established colonies on reef flats (Naim, pers. obs., Highsmith, 2002). Numerous sea urchins contribute to help Acropora muricata to be dominating by clearing primary reefal producers (McClanahan et al., 1995; Tourrand et al., 2013), and by eroding dead corals (Conand et al., 1997). In this study, the sensitivity of Acropora to environmental factors as well as its ability to quickly recolonize space, either in coverage or specific richness, when abiotic conditions are favourable, is demonstrated.

By contrast, massive corals, although possessing stress-tolerant morphologies, become the dominant forms when Acropora and other stenotopic corals are mostly excluded by environmental factors (Pastorok \& Bilyard, 1985; Rogers 1990; Edinger $\&$ Risk, 2000). At Site-P, the two submassive Montipora circumvallata and Porites (Synaraea) rus are thought to occupy the space vacated by Acropora, and particularly by the fast-growing Acropora muricata (despite the lack of long-term historical data, it may be assumed that these massive corals have occupied the outflow Site-P for a very long time). Similarly, in Great Comoro, Anasse et al. (2003) reported that, after the 1998-dramatic bleaching event, Acropora disappeared and was replaced at the beginning of 2000's by a community dominated by Melobesiae (70\% of coverage) and by Pocillopora verrucosa, Porites (Synaraea) rus and the faviids Platygyra daedalea and Favites spp. In the Caribbean, the coverage of the massive and dominant Porites astreoides is increasing on declining reefs suffering a drop in coral cover (Green et al., 2008). Similarly, long-term monitoring in Moorea (French polynesia) showed that the cover rate of Acropora, Montipora and Pocillopora are decreasing over time while Porites coverage is unaffected (Adjerouh et al., 2009).

Among environmental factors, nutrient-loading can cause large shifts in coral reef community structure (Smith et al., 1981; Lapointe et al., 1997). In Reunion, the ACR communities are autotrophically functioning at inflow sites, e.g. "Toboggan" and "Petit Trou d'eau", while the MAS communities are typified by a heterotrophic regime at outflow sites, e.g. "Planch'Alizés" and "Club Med" (Mioche 1998; Mioche et al., 2002; Conand et al., 2002).

Elevated respiration rates (Mioche, 1998) can act negatively on the Acropora metabolism at the dystrophic Site-P, as observed in 1985-86 during one year-long monitoring: large natural transplants of $A$. muricata brought by waves and resettling at Site-P, were systematically dying during the hot season (Naim, 1993), while not at Site-T. Then, hypoxyia (Herreid, 1980; Diaz \& Rosenberg, 1995) may be one of the key factors explaining the MAS coral assemblage, and MAS may be considered as the "phase shift" of ACR, sensu Done (1992), triggered by dystrophic conditions. Dystrophyia and hypoxyia may lead also to undergrazing and to primary producer dominance by feedback (Naim et al., 2013).

In addition, this study suggests that Acropora abundance and diversity, as well as the occurrence of Echinometra mathaei and Diadematidae can be used as reliable indicators for autotrophic functioning; in addition, the occurrence of Montipora circumvallata and Porites (Synaraea) rus with scarse Acropora and abundant bentic primary producers may reflect hererotrophy and freshwater enrichment (Semple, 1997; Naim et al., 2013, Tourrand et al., 2013).

The ACR characteristic species. Among autotrophic Acropora (Mioche, 1998), Acropora muricatalformosa and A.digitifera are the most abundant, and the 
later species to develop at Site-P and thus, can be considered as the most eurytopic Acropora species present in Reunion.

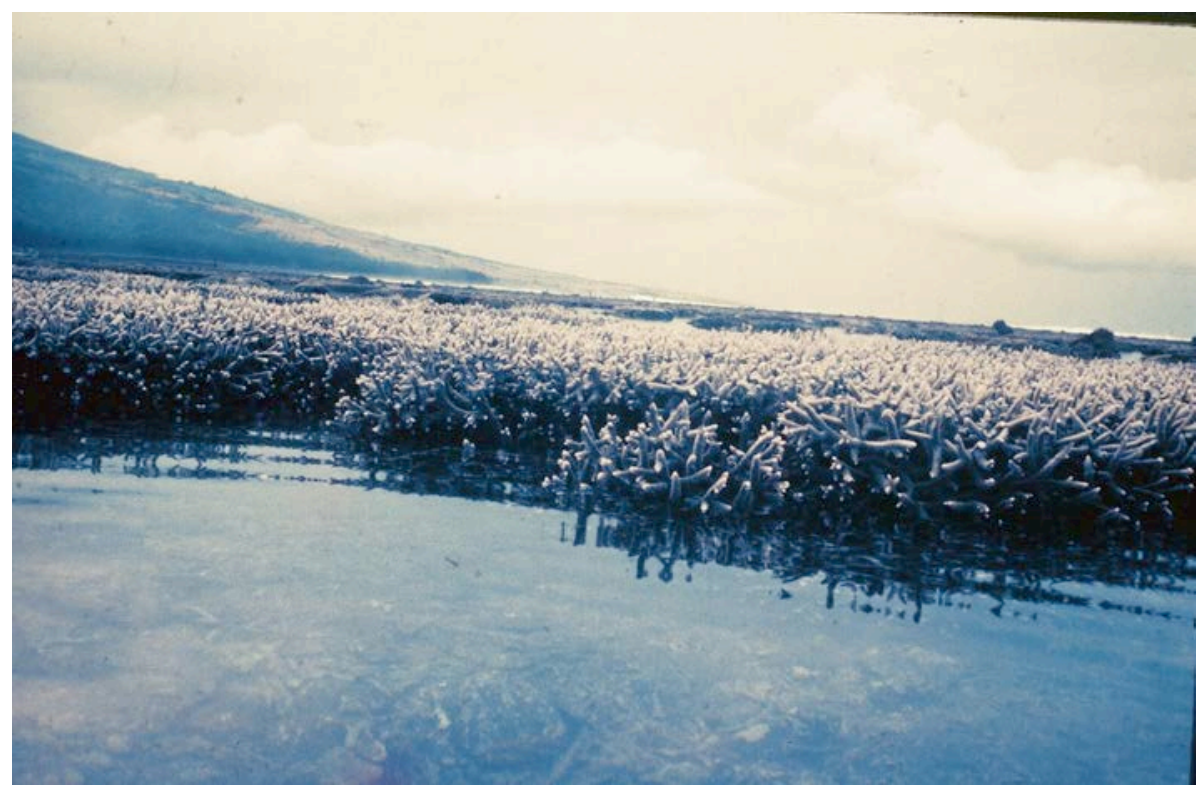

Photograph 1. 1970's. ACR community, L-zone. Acropora muricata beds at la Saline during a very low tide (Photography: G. Faure).

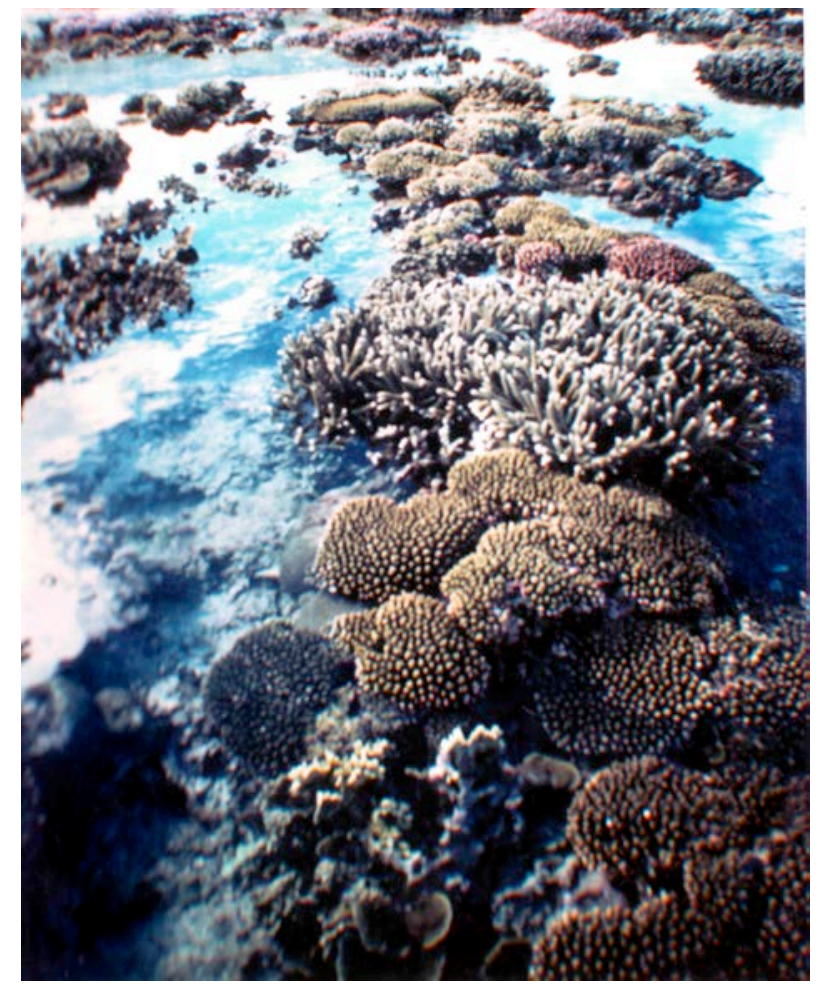

Photograph 2. 1987. ACR community, N-zone. Acropora strips during a very low tide (Photography: O. Naim).

They were and they are also among the most abundant Acropora on the SaintGilles La Saline reef flat (Faure, 2009). On oligotrophic reef flats, A.muricata can form large monospecific banks in the L-zone (ten to twenty meters wide at la Saline, Saint-Leu, Saint-Pierre, photograph 1), and Acropora-dominated narrow strips on the N-subzone (Photograph 2). However, in Reunion, monospecific coral stands do 
not reach sizes as large as those usually found in the Arabian Sea where corals, such as Montipora foliosa or Pocillopora damicornis (and other species), can develop banks extending over several hundred meters (Wilson, 2000). After the major 2009bleaching event recorded at Sites T and P (Table 5, Tourrand et al., 2013), 50\% of the bleached A.muricata recovered without problem at Site-T, but died at Site-P. This observation once more highlights the prominent role played by abiotic factors in the resilience of corals sensitive to global warming.

In contrast to Acropora muricata, Acropora austera may be considered in Reunion to be very sensitive and perhaps, one of the sentinel species on the reef flat zone. After the 2002-bleaching event affecting Acropora at Site-T, 99\% of A.austera bleached to death at Site-T whereas all the ten other Acropora species mainly recovered (Naim \& Tourrand, unpublished).

The MAS characteristic species. In the literature, there is little information on Montipora circumvallata, the dominant species encountered at Site-P. This species is regarded as rare by Veron (2000), but is, and has been, recorded as common to locally abundant in shallow inner reef flats at Reunion and Mauritius (Faure, 1982, 2009). Its successful development in nutrient-enriched areas, both in

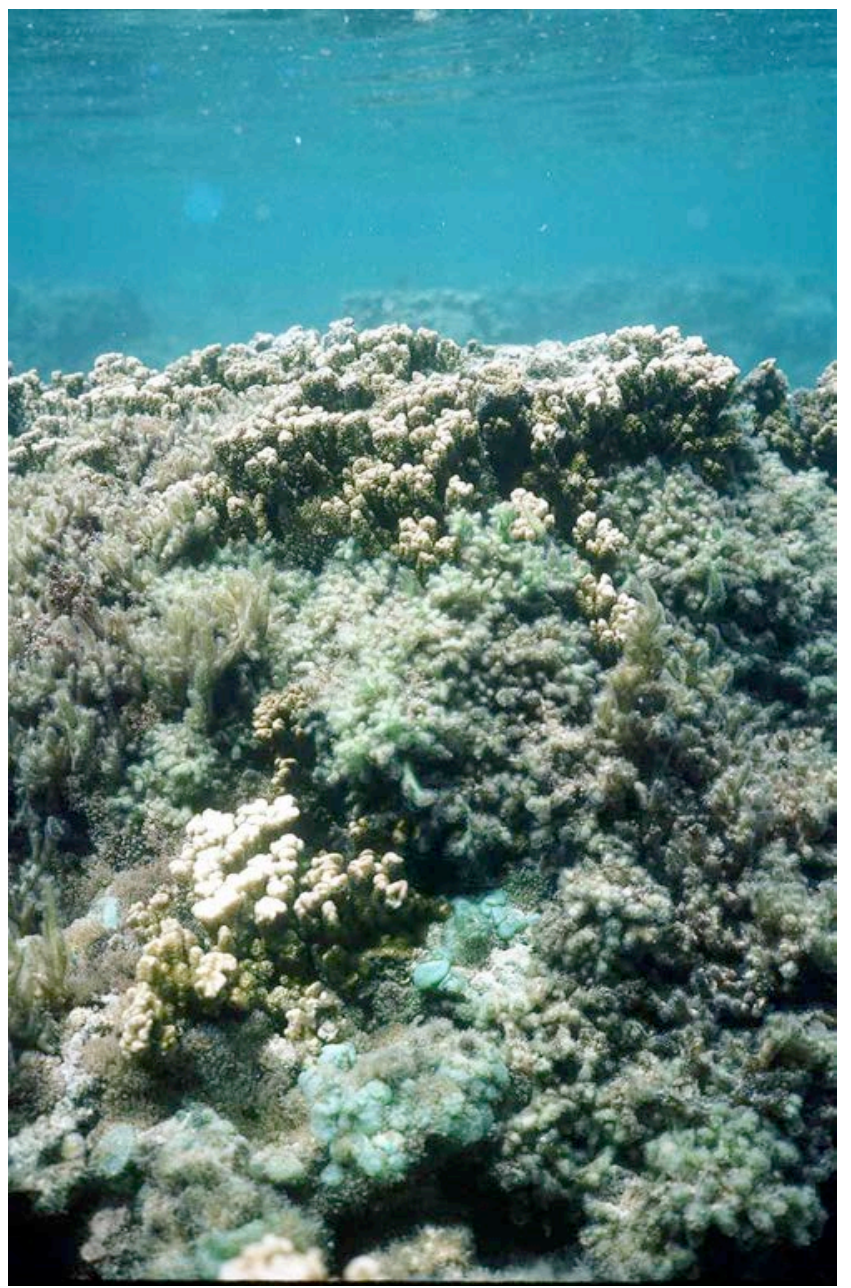

Photograph 3. 1987. Planch'Alizés (Site-P), L-zone. Montipora circumvallata buried into macroalgae (Gracilaria canaliculata, Dictyosphaearia verluysii). 
Reunion and Mauritius lagoons (Cuet \& Naim, non published), suggests that the species is favoured, or at least not disturbed, by nutrient input. Given freshwater fluxes are often accompanied by high nutrient amounts (Cuet, 1989), the development of $M$. circumvallata can be also promoted, or not disturbed, by low salinity. It may considered to be an opportunistic form which takes advantage of not competiting with Acropora. From 1985 to 2002, this species was the only Montipora recorded at SiteP, whereas M. aequituberculata and M. edwardsi were present at Site-T.

Similarly, in the famous eutrophic Kaneohe Bay (Oahu, Hawaii), Montipora verrucosa was observed to be a resistant species to the Dictyosphaeria cavernosa invasion (Banner, 1974) while Montipora dilatata declined dramatically over the past few decades (Hunter, 2009). It is interesting to note that, in outdoor tanks, Rodrigues and Grottoli (2007) showed that, after a period of eight postbleaching months, the arborescent Montipora capitata was twice as likely to recover and had a lower mortality than Porites lutea and the branching Porites compressa, both known to be very tolerant species. While bleached, Montipora capitata increased heterotrophic feeding rates to meet more than $100 \%$ of daily needs. This indicates that the resistance of Montipora varies among species: $M$. circumvallata, $M$. capitata can be considered to be stress-tolerant species, and perhaps favoured by heterotrophy (Photograph 3), while M. aequituberculata, M. edwardsi, M. dilatata can be regarded as sensitive species. Nevertheless, after a large bleaching event observed in Reunion in 2009, Montipora circumvallata was more widely affected than Porites (Synarea) rus and Porites (P.) nigrescens at Site-P, and also than Acropora formosa at Site-T (Table 5, in Tourrand et al., 2013). As Acropora is generally the most sensitive to global warming, this recent M.circumvallata demise raises the question of a possible recent change in abiotic and/or biotic (disease?) conditions at Site-P.

Porites (Synaraea) rus is a ubiquitous species, abundant in Mascarene lagoons (Faure, 1982, 2009). It can be locally dominant in the outer channels cutting the Reunion reef flats (Naim, pers. obs.).

Prevalent at Site-P (Photograph 4), P. (S.) rus has also been observed to significantly develop close to a sewage pipe in Hawaii (Dollar, 1994). This suggests that the species may be favoured by nutrient-enrichment, explaining partly its success in the MAS community. Nevertheless, in Jakarta bay (Indonesia), where humaninduced disturbance is intense, the reefs are typified by the virtual absence of otherwise abundant coral species, such as Acropora hyacinthus and Porites (S.) rus, and the prevalence of some species, such as Oulastrea crispata and Favia maxima (Cleary et al., 2006). Thus, although it appears to be euryecious and/or nutrientfavoured, $P$. (S.) rus may be nevertheless sensitive to high levels of pollution. Porites $(P$.) nigrescens appears also to be much more abundant at Site-P. By contrast, Porites (P.) lutea is not a species liable to distinguish between Sites based on its coverage, but the relevant colonies are much larger at Site-T than at Site-P. 


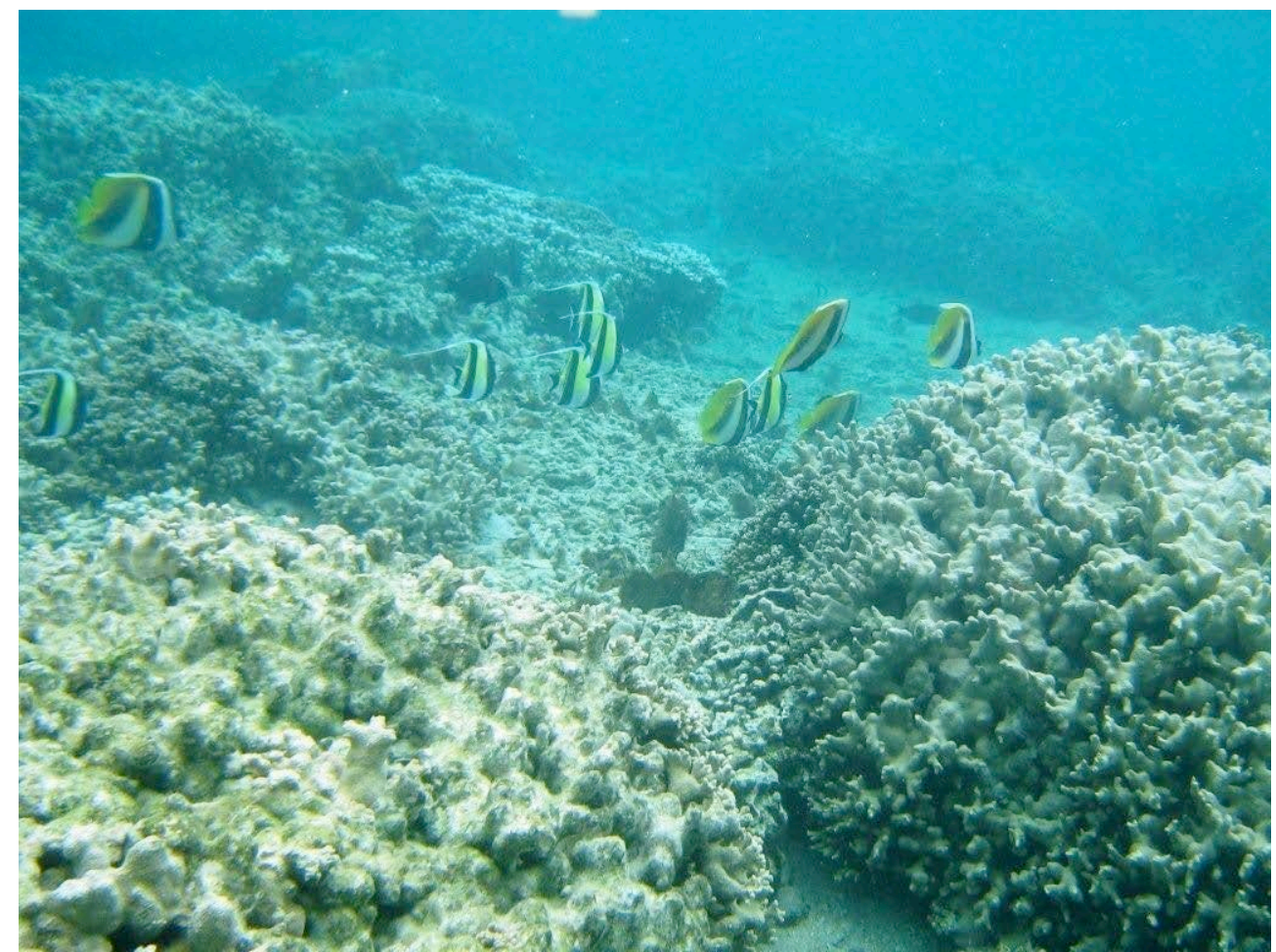

Photograph 4. 2009. Planch'Alizés (Site-P), L-zone. Porites (Synaraea) rus (photography: B Cauvin).

At Saint-Gilles La Saline, Faviidae were and are generally absent from back reefs, rather rare in $\mathrm{L}$ and $\mathrm{N}$-zones (about 150 to $330 \mathrm{~m}$ from the beach), but colonize the outer reef flats (about 350 to $550 \mathrm{~m}$ from the beach) and some of them are reef front builders (Faure, 1982, 2009). Their abundance on the Reunion incipient fringing reefs, north and south Saint-Gilles (Boucan Canot, Cap Champagne, Saint-Leu platforms) indicates that their occurrence may be correlated positively with wave agitation. The presence and richness of Faviidae at Site-P (inner L-subzone) can be linked to dystrophy, especially the presence of Goniastrea, that is often dominant on intertidal mudflats (Veron, 2000). Their occurrence at the PL subzone may also be related to the absence of spatial competition with Acropora muricata. Indeed, on the reef flat located in front of Saint-Leu city, five years after the impact of cyclone Firinga (99\% coral mortality), Faviids became extremely abundant and diversified but, 10 years after, they were totally overgrown by the fast-growing and overwhelming A.muricata (Naim et al., 1998; 2002). Similarly, on the Australian Great Barrier reef, Done \& Potts (1992) observed that young Porites were likely to die from overgrowth by much faster growing corals.

In the 1980's, in the P-coral zone, numerous Pocillopora damicornis colonies were buried by the abundant macroalgae (Photograph 5). These colonies displayed the acuta form while at Site-T the species was mostly represented by the bulbosa form (http://etic.univ-reunion.fr/ikbs/French/Pdamicornis.html). Since this time, the abundance of P.damicornis has greatly decreased at Site-P, indicating that the species could have been promoted by nutrients in 1980's, and/or young recruits may have been protected from fish grazing owing to the growth of upalatable macroalgae. 


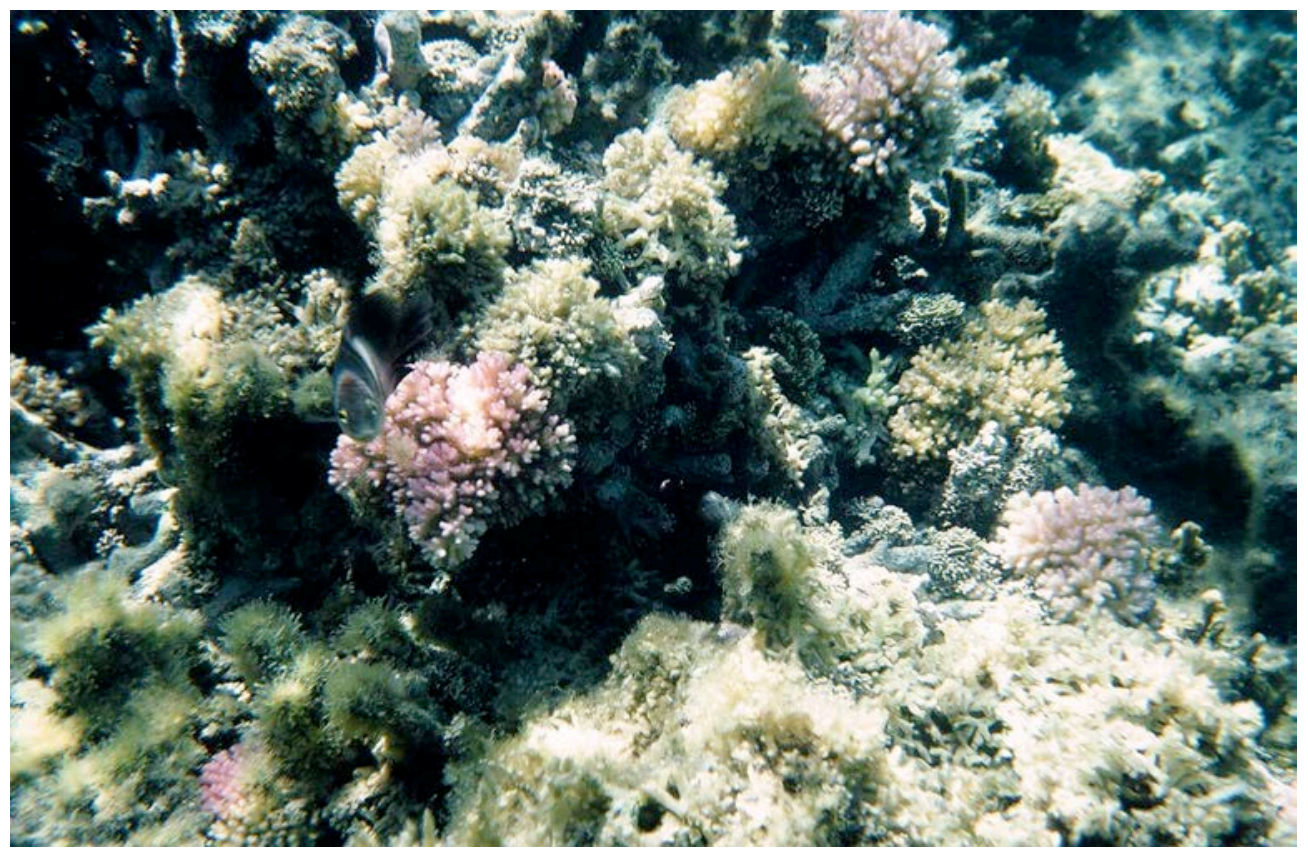

Photograph 5. 1987 Planch'Alizés (Site-P), L-zone: Numerous Pocillopora damicornis among macroalgae (photography: O. Naim).

In Tahiti, from 22 species of hard corals recorded in the Papeete polluted harbour, Pocillopora damicornis and Porites (Synaraea) rus are the only ubiquitous species, observed in the whole area (Adjerouh et al., 2000), thus suggesting their high resistance once more.

Pavona divaricata is also a dominant species at Site-P. Ubiquitous on the Reunion reefs (Faure, 1982, 2009), this species was scarse at Site-T from 1993 to 2002 , although it may develop in the form of colonies several meters in diameter at Site-Petit Trou d'eau, southern part of la Saline reef flat, an oligotrophic site, but where branching corals are not as dominant as at Site-T (Bouchon, 1996; Mioche, 1998; Naim, non published). This suggests that $P$. divaricata may be limited in part by the overwhelming increase of branching coral coverage. Concerning its resistance, $P$. divaricata was the only species, with Porites lutea, remaining alive after the huge hypersedimentation caused by the runoff after cyclone Firinga in 1989 on the SaintLeu reef flat (Naim et al., 1998; 2002). This observation therefore indicates that $P$. divaricata and $P$. lutea are highly resistant to severe change in abiotic factors.

Temporal variations: the 1999-shift

In 1999, the demise of macroalgae at Site-P reflected an important shift in the nutrient supply to the reef flat (Naim et al., 2013) resulting in an improvement in the health of massive corals. Conversely, the dramatic increase in primary producers (mostly Stegastes territory turfs) at Site-T indicated an increasing disturbance of living corals (bleaching, very low tides, etc.). However, although the massive coral coverage was increasing at Site-P from 1987 to 2009 no significant change in coral species coverage has been demonstrated. In 2007-2008, Denis et al. (2011) studying the regeneration of lesions in Porites lutea in the ACR and MAS communities at Reunion, demonstrated that lesion repair was still the poorest at Site-P. This site is 
also the one where degeneration was observed during the hot season. This indicates that, although the macroalgae disappeared and the coral health improved, corals have still not fully recovered.

Species richness and diversity

Diversity at Sites T and P. When the TL and PL-coral subzones are in their most healthy condition (2002), biodiversity was the lowest at Site-T (A.muricata dominance) and the highest at Site-P (Fig.3). At Site-T, after the high degradation suffered by Acropora in 1993, diversity first increased and later, after nine years, decreased when A.muricata became dominant in the TL and TN-coral subzones (Fig. 3b). A similar changing trend in diversity was observed on the reef flat close to SaintLeu city (Naim et al., 2002), when A.muricata reconquered space 10 years after the disturbance event.

Diversity measured at Site-T and P was to a great extent lower than that recorded by Bouchon (1996), in the 1970s on Petit Trou d'eau, south of Saline reef flat (Table 7).

Table 7. Comparison of 1970s and 1993-2002 diversity (H', Shannon index) of hard living corals (Millepora included). Petit Trou d'eau location on figure 1 (Tourrand et al., 2013).

\begin{tabular}{|c|c|c|c|}
\hline $\begin{array}{c}\mathrm{H}^{\prime} \\
\text { (Shannon index) }\end{array}$ & $\begin{array}{c}\text { Site-T ("Toboggan”) } \\
\text { mean 1993-1996-2002 (max.) } \\
\text { (Survey 1) }\end{array}$ & $\begin{array}{c}\text { Site-P (“Planch'Alizés") } \\
\text { mean 1993-1996-2002 (max) } \\
\text { (Survey 1) }\end{array}$ & $\begin{array}{c}\text { Site-PTE ("Petit Trou d'eau”) } \\
1976 \\
\text { (Bouchon, 1996) }\end{array}$ \\
\hline B-subzone & $\begin{array}{c}1.75 \\
(\max .1 .66 \text { in 1993) }\end{array}$ & $\begin{array}{c}1.49 \\
(\max .1 .58 \text { in } 2002)\end{array}$ & 3.25 \\
\hline L-subzone & $\begin{array}{c}0.89 \\
\text { ( } \max .0 .97 \text { in } 1993 \& 1996)\end{array}$ & $\begin{array}{c}1.15 \\
(\max .1 .31 \text { in } 2002)\end{array}$ & 3.00 \\
\hline N-subzone & $\begin{array}{c}2.06 \\
(\max .2 .29 \text { in } 1996)\end{array}$ & $\begin{array}{c}1.56 \\
(\max .1 .60 \text { in } 1996)\end{array}$ & 3.25 \\
\hline
\end{tabular}

These findings can be explained by the fact that both Sites $\mathrm{T}$ and $\mathrm{P}$ expressed two extreme situations: a very high dominance of Acropora at Site-T (i.e. a «pure » ACR community) and a scarceness of Acropora at Site-P (i.e. a «pure » MAS community). Although experiencing autotrophy (Mioche, 1998), the Site-Petit trou d'eau can be considered to be a transitional site where diverse Acropora and nonAcropora communities occur (Naim, unpublished). This may be also explained by a global loss in coral diversity from the 1970s to the 2000s. Further quantitative investigations at Site-Petit Trou d'eau are needed to define more precisely the evolution of coral diversity from the 1970s.

Species richness at the scale of Reunion reefs. Faure et al. (2008b) give a list of corals identified from the Faure's coral collection (1982), referring to 14 families, 53 genera and 190 species of hard corals in the Mascarene Islands. However, marine richness and diversity showed a general decrease in the islands (Bourmaud et al., 2006). According to these authors and the Marine Species Data Base for Eastern Africa (MASDEA, http://www.vliz.be/vmdcdata/masdea/), Reunion still harbours $42 \%$ of the Cnidarians recorded in the region. This percentage is considered to be high, relative to the age of the island (2.1 million years, Bachèlery, 2000) and the small size of its fringing reefs. Recent discovery of four new species of Octocorallians (Benayahu \& van Ofwegen, 2012; Schleyer, non published) highlights 
again the possible endemism and thus, the fragility of the marine communities in a remote island such as Reunion.

Between 1993 and 2002, 36 species were recorded at the Sites T and P (16.500 $\mathrm{m}^{2}$ explored in each one). In 2007, Bruggemann et al., using the Coral Count Point method, recorded 22 species on 4 stations located in the Saline outer N-zone.

At a much larger scale, two studies yielded a qualitative and semi-quantitative inventory of the Reunion living coral species in each habitat, the first carried out in the 1970s throughout the Mascarene reefs (Faure, 1982) and the second in 2009 restricted to the Reunion reefs (Faure, 2009). In 40 years, the species richness slightly decreased but remains high on reef flats (1970s: 74 species recorded; 2009: 71 species, of which on inner reef flats $(\mathrm{B}+\mathrm{L}+\mathrm{N}$ zones): 36 species and on outer reef flats: 62 species).

The decrease in richness was due to the demise of Stylophora. Widely growing in the 1970s, the genus appeared totally absent in 2009. Athough Stylophora pistillata, preferring calm conditions, usually was rare in the exposed Reunion reef settings, $S$. mordax was a common species on the reef flats and outer slopes in SaintGilles La Saline and St-Leu (Faure, 1982). This species now seems to be located only on areas of high water energy, like those related to the incipient reefs at Boucan Canot and Grand Fond, and to the outer slopes off Saint-Leu city.

Similarly, the abundance/dominance of Faviidae, mainly of Favia rotumana, dereased on the outer reef flats from 1970s to 2009. In the 1985-2000 intermediary period, a number of surveys confirmed that Stylophora as well as Favia rotumana already were almost absent on Saint-Gilles La Saline reef flat (Naim, pers. obs.). As for Stylophora, Faviids are still numerous and diverse on Reunion incipient reefs, and on the exposed reef flats of Saint-Leu.

Hypotheses to explain the decrease in coral species richness

Decrease in Stylophora. By studying the reproduction of Stylophora pistillata at Eilat (Israel), Rinkevitch \& Loya (1979) showed that fecundity was four times lower on a chronically polluted reef, compared to a control oligotrophic site. The population affected exhibited fewer breeding colonies, fewer ovaries and planulae per polyp, and a marked decrease in the reproductive index. Similarly, Loya et al. (2004) strongly suggested that nutrients released from fish farms have adverse effects on successful production of S. pistillata larvae. In Saint-Gilles La Saline, as cropland and urbanized areas have developed tremendously on the watershed over the last 40 years, the decrease of Stylophora may be due to the supply of more (or new) pollutants to the reef.

Considering bleaching, some species are more suceptible to this disturbance than others, as evidenced by shifts in community composition (Loya et al., 2001, in which Porites is the «winner » in Okinawa reefs). Branching and plate-shaped corals, such as Acropora, Montipora, and Seriatopora, may have higher mortality rates after bleaching events (Birkeland, 1977; Adjeroud et al., 2009 ; Fitt et al., 2009 ;

McClanahan, 2004 ; McClanahan et al., 2004). Surveys in Kenya and Madagascar during the 1998-bleaching event revealed that Montipora and Favia displayed a high susceptibility to bleaching (>70\%) but had low mortality rates as compared to Acropora and Stylophora, which had the highest frequencies of mortality (Hsieh et al., 2000). Stylophora was considered by Fitts et al. (2009) to be «thermallysensitive ». By using Stylophora pistillata as a model, Sampayo et al. (2008) 
monitored individual in-situ colonies over a two-year period and showed that fine level genetic variability in symbionts (within clade C) was positively correlated to differences in bleaching susceptibility.

Furthermore, the impact of reef trampling is well documented (Woodland \& Hopper, 1977). Before 2007, Reunion reef flats used to be harvested by people at spring low tide (for Octopus, molluscs, etc.), and Stylophora was mostly located on the trampling zones. However, although the species has a strong matrix and can resist mechanical human impacts, perhaps this is not the case for young recruits. Further investigations would be therefore required for identifying the controlling factors of the Stylophora demise at Saint-Gilles-La Saline over the last two decades.

Decrease in Faviidae. McClanahan (2004) recorded that during a bleaching event, Favia, Favites, Goniopora, and Leptoria, did not die. Similarly, in Reunion, observations on recovery after bleaching showed that, although they bleach, few Faviids die after bleaching, especially on the incipient reefs and exposed reef flats where these corals are abundant (Naim, unpublished). The regression of Faviids may be also attributed to pollution/trampling or to a combination of ecological factors. In Saint-Gilles La Saline, surveys of the two newly established sanctuaries (2007) and within reef areas opened to human activities, will help to understand the impact of trampling on the recruitment of reef-flat corals.

\section{CONCLUSION}

In many cases, it is difficult to pinpoint the exact causes of coral decline that is currently happening around the world. Degradation frequently occurs through the interaction of a combination of human-derived and natural factors, which then leads reef communities to become less resistant to natural disturbances (Done, 1992). If in Reunion and Mauritius, the MAS communities appear to be mainly the result of nutrient inputs and undergrazing (this study ; Cuet \& Naim, non published), they reflect also the physiological capacities of the massive and submassive corals to resist large variation in abiotic factors (temperature, salinity, etc.) and pollutants (Edinger \& Risk, 2000). They are regarded therefore as highly resistant communities.

The reefs rich in Acropora (the ACR community) show an aesthetism, a myriad of colors and forms, a diversity not seen in the MAS communities (Chabanet \& Faure, 1994; Chabanet et al., 1997). In the Indian Ocean, Acropora is becoming a rare genus in many reefs that have been heavily impacted by the 1998-bleaching event (Obura et al., eds, 2008). But these fragile ACR communities, are still dominant on the Reunion reef flats. Even though coral bleaching poses a serious threat to these Acropora-dominated communities, they are able to recover rapidly if oceanographic, ecological and physiological factors remain favourable (Tourrand $e t$ al., 2013), and can still be considered to be resilient in Reunion.

In Reunion, the human pressure has hugely increased. The population of the island is expected to grow at an annual rate of $1.1 \%$ in the next ten years. Most inhabitants are living along the coast, and the Saint-Gilles La Saline coral reefs are the most attractive for beach activities and tourism. In addition, large amounts of freshwater are at present supplied from the eastern coast, thus promoting urbanization along the western island flanks (Borca \& Margoloff, 2004; Cuet, 2007). 
Accordingly, the western coastal areas are more and more populous and there is high pressure on the watershed for developing agricultural activities, building tourism infrastructures and new homes. That is why our efforts must focus on better management of these fragile coral communities, particularly through the Marine Reserve action (http://www.reservemarinereunion.fr/). The management should focus, among other things, on reducing « hidden » pollution, including chemical and pesticide inputs, coming via polluted run-off (ravines, sewage plants) and via freshwater seepage onto reef flats and slopes.

\section{ACKNOWLEDGEMENTS}

We thank M. Daniel CHOUSSY $\dagger$ for his assistance during fieldwork. We also thank Professor Terence J. DONE for rereading this paper. This project was funded by the « programme quadriennal laboratoire ECOMAR, université de la Réunion, Région Réunion » and the «Ministère de l'Enseignement Supérieur et de la Recherche (MESR)».

\section{REFERENCES}

Adjerouh, M., S. Planes and B. Delesalle

2000. Coral and fish communities in a disturbed environment: Papeete harbor, Tahiti. Atoll Research Bulletin 484: 1-6.

Adjeroud, M., F. Michonneau, P.J. Edmunds, Y. Chancerelle, T. Lison de Loma, L. Penin, L. Thibaut, J. Vidal-Dupiol, B. Salvat and R. Galzin

2009. Recurrent disturbances, recovery trajectories, and resilience of coral assemblages on a South Central Pacific reef. Coral Reefs 28: 775-780.

Anasse, F., S. Ahamada, J. Jantzen, L. Bigot, J.-P. Quod, O. Tyack, Y. Hamadi, M. Hamidou and S. Ahamed

2003. Atlas de vulnérabilité des zones coralliennes peu profondes sud et nord de la Grande Comore. Union des Comores, Projet régional environnement 7, ACP.RPR.068, AIDE, ARVAM, DGE, CNDRS, $51 \mathrm{pp}$

Ateweberhan, M., T.R. McClanahan, N.A.J. Graham and C.R.C. Sheppard

2011. Episodic heterogeneous decline and recovery of coral cover in the Indian Ocean. Coral Reefs 30: 739-752.

Bachèlery, $\mathrm{P}$.

2000. Origin of the Mascarene Islands. In: Coral reefs of the Indian Ocean: their Ecology and Conservation (McClanahan, T., Sheppard, C., Obura, D.O. eds), Oxford Univ. Press, Pp. 360-361.

Banner, A.H.

1974. Kaneohe Bay, Hawaii: urban pollution and a coral reef ecosystem. Proceedings of the $2^{\text {nd }}$ International Coral Reef Symposium, Brisbane, Australia 2: 685-702.

Bellwood, D.R., T.P. Hughes, C. Folke and M. Nystroëm

2004. Confronting the coral reef crisis. Nature 429: 827-833.

Benayahu, Y. and L.P. van Ofwegen

2012. Octocorals (Cnidaria, Anthozoa) from Reunion, with a description of two new species of the genus Sinularia May, 1898 and notes on the occurrence of other species. Zoosystema, 34 (4): 673-699.

Birkeland, C.

1977. Disturbances to reefs in recent times. In: Life and death of coral reefs (Birkeland, C., ed.), Chapman and hall, New York, Pp 365-367.

Borca, T. and N. Margoloff 
2004. Basculement des eaux de la Réunion: Un chantier titanesque. La Reunion Island: shifting waters from East to West, a giant jobsite. Tunnels et ouvrages souterrains, ISSN 0399-0834, CODEN TNOSAI $182: 71-74$.

Bouchon, C.

1996. Recherche sur les peuplements de Scléractinaires Indo-Pacifiques (Mer Rouge, Océan Indien, Océan Pacifique). Doctorat ès Sciences, Univ. Aix-Marseille II, 338 pp.

Bourmaud, C.A-F., L. Leclere, P. Mangion, F. Michonneau and G. Pennober

2006. Biodiversity of Reunion coral reefs. Proceedings of the $10^{\text {th }}$ International Coral Reef Symposium, Okinawa, Japan 2: 207-212.

Bruggemann, H., M.M.M. Guillaume, V. Denis, L. Bigot, O. Naim, M. Tessier, P. Durville and T. Mulochau

2007. The recent marine reserve at Reunion Island: Initial state of the benthic communities of the coral reefs of Saint-Leu and la Saline. Proceedings of the $5^{\text {th }}$ Western Indian Ocean Marine Science Association (WIOMSA) Conference, Durban, Souh Africa, abstract

Bruno, J.F. and E.R. Selig

2007. Regional Decline of Coral Cover in the Indo-Pacific: timing, extent, and subregional comparisons. PLoS ONE 2 (8): e711.

Carpenter, K.E., M. Abrar, G. Aeby, R.B. Aronson, S. Banks, A. Bruckner, A. Chiriboga, J. Cortes, J.C. Delbeek and L. De Vantier

2008. One-third of reef-building corals face elevated extinction risk from climate change and local impacts. Science 321: 560-563.

Chabanet, P.

1994. Étude des relations entre les peuplements coralliens et les peuplements ichtyologiques sur le complexe récifal de Saint-Gilles La Saline. Doct. spéc. Environnement marin, Univ. AixMarseille III, France, 200 pp.

Chabanet, P. and G.F. Faure

1994. Interrelations entre peuplements benthiques et ichtyologiques en milieu corallien. Comptes Rendus à l' Académie des Sciences, Paris 317: 1151-1157.

Chabanet, P., H. Ralambondrainy, M. Amanieu, G.F. Faure and R. Galzin

1997. Relationships between coral reef substrata and fish. Coral Reefs 16: 93-102.

Cleary, D.F.R., Suharsono and B.W. Hoeksema

2006. Coral diversity across a disturbance gradient in the Pulau Seribu complex off Jakarta, Indonesia. Biodiversity and Conservation 15 (11): 3653-3674.

Conand, C., P. Chabanet, P. Cuet, and Y. Letourneur

1997. The carbonate budget of a fringing reef in la Reunion Island (Indian Ocean): sea urchin and fish bioerosion and net calcification. Proceedings of the $8^{\text {th }}$ International Coral Reef Symposium, Smithsonian Tropical Research Institute, Panama 1: 953-958.

Conand, C., P. Cuet, O. Naim and D. Mioche

2002. Des coraux sous surveillance. Pour la Science, 298 : 75-81.

Cuet, P.

1989. Influence des résurgences d'eau douce sur les caractéristiques physico-chimiques et métaboliques de l'écosystème récifal à La Réunion. Doctorat de spécialité en Environnement marin, Univ. Aix-Marseille III, France, 204 pp.

2007. Influence de l'irrigation du littoral Ouest sur la qualité du milieu naturel. Suivi du réseau qualitatif Antenne 4. Années 2004-2005 et synthèse 1999-2005 (rapport final). Rapport Université de la Réunion - Département de la Réunion, 77 pp.

Denis, V., J. Debreuil, S. De Palmas, J. Richard, M.M.M. Guillaume and H. Bruggemann

2011. Lesion regeneration capacities in population of the massive coral Porites lutea at Reunion Island: environmental correlates. Marine Ecology Progress Series 428: 105-117.

Despinoy, M., M. Petit, A. Minghelli-Roman and O. Naim

2000. Hyperspectral remote sensing and high spatial resolution: a relevant tool for a cartography of coral reef systems. International Coral Reef Initiative (ICRI) meeting, Communication and poster on la Saline reef communities.

Diaz, R.J. and R. Rosenberg 
1995. Marine benthic hypoxia: a review of its ecological effects ans the behavioural responses of benthic macrofauna. Oceanography and Marine Biology: an annual review 33: 245-303.

Dollar, S.

1994. Sewage discharge on coral reefs: not always pollution. Coral reefs 13: 224.

Done, T.J.

1992. Phase shifts in coral communities and their ecological significance. Hydrobiologia 247: 121-132.

Done, T. J. and D.C. Potts

1992. Influences of habitat and natural disturbances on contributions of massive Porites corals to reef communities. Marine Biology 114 (3): 479-493.

Edinger, E.N. and M.J. Risk

2000. Reef classification by coral morphology predicts coral reef conservation value. Biological Conservation 92: 1-13.

Faure, G.F.

1982. Recherche sur les peuplements de Scléractiniaires des récifs coralliens de l'Archipel des Mascareignes (Océan Indien Occidental). Doctorat ès Sciences, Univ. Aix-Marseille II, vol.1 \& 2.

2009. Biodiversité des Scléractiniaires, la Saline 2009. Rapport non publié Réserve marine Réunion, $10 \mathrm{pp}$.

Faure, G.F., M. Pichon, F. Trentin, Y. Geynet, N. Conruyt, P. Gigord and D. Caron

2008a. Base de connaissance sur les coraux des Mascareignes (Iterative Knowledge Base System, IKBS). Univ. Réunion, 50pp. http://coraux.univ-reunion.fr

Faure, G.F., M. Pichon and Y. Geynet

2008b. List of Scleractinian coral species cited from the Mascarene archipelago based on Faure (1982). IUCN

Fitt, W.K., R.D. Gates, O. Hoegh-Guldberg, J.C. Bythell, A. Jatkar, A.G. Grottoli, M. Gomez, P. Fisher, T.C. Lajuenesse, O. Pantos et al.

2009. Response of two species of Indo-Pacific corals, Porites cylindrica and Stylophora pistillata to short-term thermal stress: the host does matter in determining the tolerance of corals to bleaching. Journal of Experimental Marine Biology and Ecology 373: 102-110.

Frontier, S.

1985. Diversity and structure in aquatic ecosystems. Oceanography and Marine Biology: An Annual Review 23: 253-312.

Gardner, T.A., I.M. Cote, J.A. Gill, A. Grant and A.R. Watkinson

2003. Long-term region-wide declines in Caribbean corals. Science 301: 958-960.

Green, D. H., P.J. Edmunds and R.C. Carpenter

2008. Increasing relative abundance of Porites astreoides on Caribbean reefs mediated by an overall decline in coral cover. Marine Ecology Progress Series 359 (1-10): 271-283.

Guillaume, M.M.M., C.E. Payri and G.F. Faure

1983. Blatant degradation of coral reefs at la Reunion Island (West Indian Ocean). International Society for Reef Studies, annual meeting, Nice, France 28.

Herreid, C.F.

1980. Hypoxia in invertebrates. Comparative Biochemistry and Physiology 67A: 311-320.

Highsmith, R.C.

1982. Reproduction by fragmentation in corals. Marine Ecology Progress Series 7: 207-226.

Hsieh, C.-I., R. Ormond and D.O. Obura

2000. Coral bleaching in the Indian Ocean and the El Niño Southern Oscillation. In: Coral reefs of the Indian Ocean : their Ecology and Conservation (McClanahan, T., Sheppard, C., Obura, D.O. eds), Oxford Univ. Press, Pp. 72-74.

Hunter, C.

2009. Distribution and abundance of Montipora dilatata in Kaneohe Bay, Oahu, Hawaii.

University Hawaii-Manoa, BIOL 403, NOAA Contract Number: 133F08SE2838, 14 p.

Lapointe, B.E., M.M. Littler and D.S. Littler 
1997. Macroalgal overgrowth of fringing coral reefs at Discovery Bay, Jamaica: bottom-up versus top-down control. Proceedings of the $8^{\text {th }}$ International Coral Reef Symposium, Townsville, Australia 1: 927-932.

Letourneur, Y.

1992. Dynamique des peuplements ichtyologiques des platiers récifaux de l'île de la Réunion. Doctorat de spécialité en Océanologie, Universités Perpignan-Réunion, France, 244 pp.

Letourneur, Y., P. Chabanet, L. Vigliola, and M.L. Harmelin-Vivien

1998. Mass settlement and post-settlement mortality patterns of juvenile Epinephelus $\underline{\text { merra }}$ Bloch (Pisces, Serranidae) on Reunion coral reefs. Journal of the Marine Biological Association of the United Kingdom 78: 307-319.

Loya, Y.

1978. Plotless and transect methods. In: Coral research methods (Stoddart D.R., Johannes R.E., eds). UNESCO, Paris, Pp. 197-217.

Loya, Y., K. Sakai, K. Yamazato, Y. Nakano, H. Sambali and R. van Woesik

2001. Coral bleaching: the winners and the losers. Ecology Letters 4: 122-131.

Loya, Y., H. Lubinevsky, M. Rosenfeld and E. Kramarsky-Winter

2004. Nutrient enrichment caused by in situ fish farms at Eilat, Red Sea is detrimental to coral reproduction. Marine Pollution Bulletin 49: 344-353.

Lucas, H.A. and G.A.F. Seber

1977. Estimating coverage and particle density using the line intercept method. Biometrika 64 (3): 618-622.

McClanahan, T.R.

2004. The relationship between bleaching and mortality of common corals. Marine Biology 144: $1239-1245$.

McClanahan, T.R., A.T. Kamukuru, N.A. Muthiga, M. Gilagabher Yebio and D.O. Obura

1995. Effect of sea urchin reduction on algae, coral and fish populations. Conservation Biology 10: 136-154.

McClanahan, T.R., A.H. Baird, P.A. Marshall and M.A. Toscano

2004. Comparing bleaching and mortality responses of hard corals between southern Kenya and the Great Barrier Reef, Australia. Marine Pollution Bulletin 48: 327-335.

McClanahan, T.R., M. Ateweberhan, C. Ruiz Sebastian, N.A.J. Graham, S.K. Wilson, H. Bruggemann and M.M.M. Guillaume

2007. Predictability of coral bleaching from synoptic satellite and in situ temperature observations. Coral Reefs 26: 695-701.

Mioche, D.

1998. Aspects du cycle de la matière sur les récifs frangeants de l'île de la Réunion (Océan Indien): signature des dégradations et mécanismes de l'eutrophisation. Doctorat de Spécialité en Écologie Marine, Université Réunion, France, 292 pp.

Mioche, D., R. Troadec, N. Germain, C. Esbelin, C. Tourrand, M. Psaradellis, O. Naim and J. Coudray

2002. Relations entre l'équilibre sédimentaire des plages, la structure des communautés et le budget des carbonates dans l'écosystème corallien de la Réunion. The Journal of Nature (Reunion) 14 (1): 35-43.

Montaggioni, L. and P. Nativel

1988. La Réunion-Maurice: géologie et aperçus biologiques. Guides Géologiques Régionaux. Ed. Masson, Paris, 192 p.

Naim, O.

1993. Seasonal responses of a fringing reef community to eutrophication (Reunion Island, western Indian Ocean). Marine Ecology Progress Series 99: 307-315.

2002. Acropora formosa (Dana, 1846) (Anthozoaire, Scléractiniaire), une espèce de corail structurant les biocénoses de platiers récifaux (Ile de la Réunion, S.O. Océan Indien). The Journal of Nature (Bourbon Sciences) 14 (3): 27-35.

2006. The coral reef communities at Saint-Gilles La Saline in 1987 (Reunion Isl., S.W. Indian Ocean). The Journal of Nature (Reunion)18(1) : 13-33.

Naim, O. and P. Cuet 
2002. Benthic community structure versus nitrate input at Reunion (SW Indian Ocean). Proceedings of the $9^{\text {th }}$ International Coral Reef Symposium, Bali, Indonesia, summary.

Naim, O., G.F. Faure and A. Engelmann

1998. Coral recolonization three years after the impact of a cyclone on a reef flat (Saint-Leu, Reunion, SW Indian Ocean). International Society for Reef Studies, annual meeting, Perpignan, France, abstract

Naim, O., P. Cuet and V. Mangar

2000. The Mascarene Islands. In: Coral reefs of the Indian Ocean: their Ecology and Conservation (McClanahan, T., Sheppard, C., Obura, D.O. eds), Oxford Univ. Press, Pp. 353-381.

Naim, O., P. Chabanet, T. Done, C. Tourrand and Y. Letourneur

2002. Regeneration of a reef flat ten years after the impact of the cyclone Firinga (Reunion, SW Indian Ocean). Proceedings of the $9^{\text {th }}$ International Coral Reef Symposium, Bali, Indonesia, 1: $547-552$.

Naim, O., C. Tourrand, E. Ballesteros, S. Semple, L. Bigot, B. Cauvin, P. Cuet and L.F. Montaggioni

2013. Fringing reefs of Reunion Island and eutrophication effects. Part 2: Long-term monitoring of primary producers. Atoll Research Bulletin 597, $36 \mathrm{p}$.

Obura, D.O, J. Tamelander and O. Lindèn, O. eds

2008. Coral Reef Degradation in the Indian Ocean (CORDIO). Status report. 2 vol., 494 pp.

Pastorok, R.A. and G.R. Bilyard

1985. Effects of sewage pollution on coral-reef communities. Marine Ecology Progress Series 21: 175-189.

Ribes, S.

1978. La macrofaune vagile associée à la partie vivante des Scléractiniaires sur un récif frangeant de l'île de la Réunion (océan Indien). Doctorat de spécialité en Océanologie, Université Aix-Marseille II, 150p.

Rinkevitch, B. and Y. Loya

1979. The reproduction of the Red Sea coral Stylophora pistillata. I. Gonads and planulae. Marine Ecology Progress Series 1, 133-144.

Rodrigues, L.J. and A.G. Grottoli

2007. Energy reserves and metabolism as indicators of coral recovery from bleaching. Limnology and Oceanography 52, 1874-1882.

Rogers, C.S.

1990. Responses of coral reefs and reef organisms to sedimentation. Marine Ecology Progress Series 62: 185-202.

Sampayo, E.M., T. Ridgway, P. Bongaerts and O. Hoegh-Guldberg

2008. Bleaching susceptibility and mortality of corals are determined by fine-scale differences in symbiont type. Proceedings of the National Academy of Sciences, U.S.A. 105 (30): 1044410449.

Semple, S.

1997. The use of temporal variations in algal cover and biomass as a tool for the quantification of the degree of eutrophication of a fringing coral reef in Reunion Island, S.W. Indian Ocean. Oceanologica Acta 20 (6): 851-861.

Sheppard, C.R.C.

2000. Coral reefs of the Western Indian Ocean: an overview. In: Coral reefs of the Indian Ocean : their Ecology and Conservation (McClanahan, T., Sheppard, C., Obura, D.O. eds), Oxford Univ. Press, Pp. 3-38.

Smith, S.V., W.J. Kimmerer, E.A. Laws, R.E. Brock and T.W. Walsh

1981. Kaneohe Bay sewage diversion experiment : perspectives on ecosystem responses to nutritional perturbation. Pacific Science 35 (4): 279-395.

Tessier, E., L. Bigot, C. Cadet, B. Cauvin, P. Chabanet, C. Conand, J.-B. Nicet and J.-P. Quod

2008. Les récifs coralliens de la Réunion en 2007: état des lieux et réseau de suivi. Revue d'Ecologie (Terre \& Vie) 63: 85-102. 
Tourrand, C., O. Naim, L. Bigot, C. Cadet, B. Cauvin, S. Semple, L.F. Montaggioni, P. Chabanet and H. Bruggemann

2013. Fringing reefs of Reunion Island and eutrophication effects. Part 1: Long-term monitoring of two shallow coral reef communities. Atoll Research Bulletin 596, 35 p.

Turner, J. and R. Klaus

2005. Coral reefs of the Mascarenes,Western Indian Ocean. Philosophical Transaction of the Royal Society A 363: 229-250.

Veron, J.E.N.

2000. Corals of the world (M. Stafford-Smith ed.). Australian Institute of Marine Science and CRR, Qld Pty Ltd, Townsville, 3 vol., 1381 pp.

Wallace, C.

1999. Staghorn corals of the world. A revision of the genus Acropora. CSIRO Publication, Melbourne, $422 \mathrm{pp}$.

Wilson, $\mathrm{S}$.

2000. Monospecific reef formations. In: Coral reefs of the Indian Ocean : their Ecology and Conservation (McClanahan, T., Sheppard, C., Obura, D.O. eds), Oxford Univ. Press, Pp. 285-286.

Woodland, R.V. and N.A. Hopper

1977. The effect of human trampling on coral reefs. Biological Conservation 11: 1-14. 